Natural Hazards and Earth System Sciences, 5, 527-554, 2005

SRef-ID: 1684-9981/nhess/2005-5-527

European Geosciences Union

(C) 2005 Author(s). This work is licensed

under a Creative Commons License.

\title{
Remote sensing of glacier- and permafrost-related hazards in high mountains: an overview
}

\author{
A. Kääb ${ }^{1}$, C. Huggel ${ }^{1}$, L. Fischer ${ }^{1}$, S. Guex ${ }^{1}$, F. Paul ${ }^{1}$, I. Roer ${ }^{2}$, N. Salzmann ${ }^{1}$, S. Schlaefli ${ }^{1}$, K. Schmutz ${ }^{1}$, \\ D. Schneider ${ }^{1}$, T. Strozzi ${ }^{3}$, and Y. Weidmann ${ }^{4}$ \\ ${ }^{1}$ Department of Geography, University of Zurich, Switzerland \\ ${ }^{2}$ Department of Geography, University of Bonn, Germany \\ ${ }^{3}$ Gamma Remote Sensing, Berne, Switzerland \\ ${ }^{4}$ University of Applied Sciences, Muttenz, Basel, Switzerland
}

Received: 9 May 2005 - Revised: 1 July 2005 - Accepted: 1 July 2005 - Published: 29 July 2005

\begin{abstract}
Process interactions and chain reactions, the present shift of cryospheric hazard zones due to atmospheric warming, and the potential far reach of glacier disasters make it necessary to apply modern remote sensing techniques for the assessment of glacier and permafrost hazards in highmountains. Typically, related hazard source areas are situated in remote regions, often difficult to access for physical and/or political reasons. In this contribution we provide an overview of air- and spaceborne remote sensing methods suitable for glacier and permafrost hazard assessment and disaster management. A number of image classification and change detection techniques support high-mountain hazard studies. Digital terrain models (DTMs), derived from optical stereo data, synthetic aperture radar or laserscanning, represent one of the most important data sets for investigating high-mountain processes. Fusion of satellite stereo-derived DTMs with the DTM from the Shuttle Radar Topography Mission (SRTM) is a promising way to combine the advantages of both technologies. Large changes in terrain volume such as from avalanche deposits can indeed be measured even by repeat satellite DTMs. Multitemporal data can be used to derive surface displacements on glaciers, permafrost and landslides. Combining DTMs, results from spectral image classification, and multitemporal data from change detection and displacement measurements significantly improves the detection of hazard potentials. Modelling of hazardous processes based on geographic information systems (GIS) complements the remote sensing analyses towards an integrated assessment of glacier and permafrost hazards in mountains. Major present limitations in the application of remote sensing to glacier and permafrost hazards in mountains are, on the one hand, of technical nature (e.g. combination and fusion of different methods and data; improved un-
\end{abstract}

Correspondence to: A. Kääb

(kaeaeb@geo.unizh.ch) derstanding of microwave backscatter). On the other hand, better dissemination of remote sensing expertise towards institutions involved in high-mountain hazard assessment and management is needed in order to exploit the large potential of remote sensing in this field.

\section{Introduction}

The glacial, paraglacial and periglacial environment is defined, respectively, as the zone of glaciers or their action, the non-glacial zone directly conditioned by glaciation or deglaciation, and the non-glacial zone in cold regions with frost action being the predominant geomorphic process. Disasters associated to that environment can cause thousands of casualties in one event. Related damages or mitigation costs are on the order of several 100 million EUR as a long-term annual average global sum (Kääb et al., 2005). Glacier and permafrost hazards (here used as a synonym for glacial, peri-, and paraglacial hazards) in high mountains include glacierand permafrost related floods, stable and unstable glacier length changes as well as glacier fluctuations, glacier- and permafrost-related mass movements, permafrost thaw settlement and frost heave, and hazards from glacier-clad volcanoes (Table 1). Often, combinations of these (and other) processes lead to the most severe glacier and permafrost catastrophes. Whilst above direct glacier and permafrost hazards are very palpable, so too are indirect hazards, such as changes in dry-season river flows, adverse effects on mountain tourism, and related socio-economic consequences.

Assessment and management of glacial, peri- and paraglacial hazards require the application of modern integrative earth-observation techniques for a number of reasons:

- Typically, related hazard source areas are situated in remote high-mountain regions, often difficult to access 
Table 1. Overview of glacier- and permafrost-related hazards in high mountains, processes involved, important remote sensing aspects, and selected remote sensing applications (see also GAPHAZ, 2004; Huggel, 2004; Kääb et al., 2005; Quincey et al., 2005).

\begin{tabular}{|c|c|}
\hline $\begin{array}{l}\text { Hazard } \\
\text { type }\end{array}$ & Processes \\
\hline $\begin{array}{l}\text { (1) Glacier- } \\
\text { and perma- } \\
\text { frost-related } \\
\text { floods }\end{array}$ & $\begin{array}{l}\text { (1.1) Breaching of moraine dams } \\
\text { Outburst of moraine-dammed lakes. Par } \\
\text { ticularly far reaching glacier disasters (ur } \\
\text { to hundreds of } \mathrm{km} \text { ). Causes: enhancec } \\
\text { runoff; impact waves (1.5); temporary } \\
\text { damming/jamming at outlet. }\end{array}$ \\
\hline
\end{tabular}

(1.2) Failure or overtopping of ice-dams Outburst of ice-dammed lakes. Particularly far reaching glacier disasters. Often repeating for permanent ice dams. Sources: icemarginal or supraglacial lakes; temporary ice dams from ice avalanches (3.1) or glacier surges (2.1).

(1.3) Glacier outbursts

Catastrophic water discharge from the enor subglacial drainage system. Causes: geothermal or volcanic activity; temporary en- or subglacial water storage; catastrophic water release connected to surge termination (2.1).

(1.4) Breaching of thermokarst and supraglacial lakes

On ice-rich permafrost or stagnant glacier ice. Progressive lake growth through thermal convection. Outburst causes: similar to (1.1), and progressive melt of ice/permafrost dam.

\section{(1.5) Displacement waves}

Displacement-wave impacts on people, natural and artificial lake dams, and other installations. Trigger for a number of lake outburst events of types (1.1) and (1.2). Causes: lake impact from snow-, ice-, rock-avalanches, landslides, debris flows, etc.; floatation of icebergs.

\section{(1.6) Enhanced runoff from permafrost} Permafrost is for the most part impermeable for surface water, a fact that leads to runoff concentration at the permafrost table, in particular with enhanced surface runoff from snow-melt and intense rainfall; ice melt at permafrost table. Temporary water storage in or underneath permafrost is particularly difficult to investigate but suggested for rare cases (causes: taliks; ice-melt in permafrost; (temporary) water blockage in or under the permafrost?). Both phenomena, runoff concentration and water storage, may lead to unusually enhanced runoff. Potential trigger mechanisms of debris flows (4.3).

Remote sensing
Moraine-dammed lakes usually detectable
by remote sensing, in particular optical tech-
niques. Time series particularly useful for
assessing lake dynamics and estimating fu-
ture development. Assessment of moraine
dam characteristics requires high-resolution
and -precision techniques (dam geometry,
deformation, settlement, surface material,
etc.). Monitoring of associated glacier char-
acteristics (geometry, surface type), changes
and kinematics (thickness changes, veloc-
ity) may help assessing the evolution of
proglacial lakes.

Detection of ice-dammed lakes depending on temporal resolution and timing of remote sensing system; detection of ice dams depending on spatial resolution and spectral characteristics. Time series particularly useful. Monitoring of thickness changes and kinematics of long-lasting ice dams supports assessment, e.g. of floatation level.

Particularly difficult or impossible to assess due to sub-surface character.

Detection of related lakes usually requires high image resolution due to the small lake size. Time series particularly useful. Disposition of lake development partially detectable through remote sensing of surface characteristics and kinematics.

Assessment requires integrative remote sensing and modelling approaches of source processes.

Can hardly be directly investigated by remote sensing.

Selected remote sensing
applications
(Buchroithner et al.,
1982; Kääb, 1996; Ageta
et al., 2000; Haeberli et
al., 2001; Mool et al.,
2001a, b; Huggel et al.,
2002, 2004b)

(Espizua and Bengochea, 1990; Haeberli et al., 2001; Huggel et al., 2002; Kääb et al., 2003c), (Fig. 4)

(Björnsson et al., 2001) (cf. Haeberli, 1983; Walder and Driedger, 1995)

(Reynolds, 2000; Kääb and Haeberli, 2001; Wessels et al., 2002)

\section{No direct air- and space- borne remote sensing ap- plication. (cf. Haeberli and Röthlisberger, 1975; Müller, 1995; Tinti et al., 1999; Walder et al., 2003; Zweifel, 2004)}

No published remote sensing applications. (cf. Haeberli et al., 1990; Zimmermann and Haeberli, 1992) 
Table 1. Continued.

\begin{tabular}{|c|c|c|c|}
\hline $\begin{array}{l}\text { Hazard } \\
\text { type }\end{array}$ & Processes & Remote sensing & $\begin{array}{l}\text { Selected remote sensing } \\
\text { applications }\end{array}$ \\
\hline \multirow[t]{4}{*}{$\begin{array}{l}\text { (2) Glacier } \\
\text { length and } \\
\text { volume } \\
\text { changes }\end{array}$} & $\begin{array}{l}\text { (2.1) Glacier surge (unstable length change) } \\
\text { Temporary instability of large glacier parts } \\
\text { with ice velocity increased by an order of } \\
\text { magnitude (or more). Usually accompanied } \\
\text { by drastic glacier advance. Besides the di- } \\
\text { rect impact from glacier advance (overriding } \\
\text { of structures, blockage of rivers, etc), glacier } \\
\text { surges often trigger further hazards such as } \\
\text { ice-dammed lakes (1.2). Enhanced englacial } \\
\text { water storage, possibly released at surge end } \\
\text { (1.3). }\end{array}$ & $\begin{array}{l}\text { Surges can be tracked by high-frequency re- } \\
\text { mote sensing. Former glacier surges, and } \\
\text { thus surge-type glaciers, can often be recog- } \\
\text { nised from deformed, so-called "looped" } \\
\text { moraines. Geometry changes, if involved in } \\
\text { the surge disposition and build-up, can be de- } \\
\text { tected as glacier thickness changes. }\end{array}$ & $\begin{array}{l}\text { (Espizua and Ben- } \\
\text { gochea, 1990; Zhang, } \\
\text { 1992; Rolstad et al., } \\
\text { 1997; Jiskoot et al., } \\
\text { 2001; Luckman et al., } \\
\text { 2002; Strozzi et al., } \\
\text { 2002; Copland et al., } \\
\text { 2003; Dowdeswell and } \\
\text { Benham, 2003), (Figs. 1, } \\
13 \text { and 17) }\end{array}$ \\
\hline & $\begin{array}{l}\text { (2.2) Stable glacier advance } \\
\text { Advancing glaciers may inundate land, over- } \\
\text { ride installations, dam rivers and form lakes } \\
(1.2) \text {, cause ice break-offs ( } 3.1 \text { ), etc. Causes: } \\
\text { positive mass balance, ice dynamics. }\end{array}$ & $\begin{array}{l}\text { Can usually be monitored by remote sensing. } \\
\text { Glacier area changes from repeat imagery, } \\
\text { glacier mass changes from repeat DTMs. } \\
\text { Forecast best done by a combination of re- } \\
\text { mote sensing, glaciological field work and } \\
\text { modelling. }\end{array}$ & $\begin{array}{l}\text { (Kääb, 1996; Paul, 2002) } \\
\text { and many others (see } \\
\text { text) }\end{array}$ \\
\hline & $\begin{array}{l}\text { (2.3) Glacier retreat } \\
\text { Glacier retreat forms usually no direct haz- } \\
\text { ard but is able to trigger a number of sec- } \\
\text { ondary hazards such as various slope insta- } \\
\text { bilities (3). Causes and remote sensing see } \\
(2.2) \text {. }\end{array}$ & & $\begin{array}{l}\text { (Silverio and Jaquet, } \\
\text { 2005), see (2.2) and (3), } \\
\text { (Fig. 2) }\end{array}$ \\
\hline & $\begin{array}{l}\text { (2.4) Changes in glacier runoff and season- } \\
\text { ality } \\
\text { Glacier mass loss leads to reduction of wa- } \\
\text { ter resources as stored in glaciers and to } \\
\text { changes in dry-season river flows. Short- } \\
\text { term perspective: increasing discharge due } \\
\text { to enhanced melt; long-term perspective: de- } \\
\text { creasing discharge when glaciers become } \\
\text { substantially smaller or disappear. Conse- } \\
\text { quences for drinking water supply, irrigation, } \\
\text { hydropower production, industrial water use, } \\
\text { fishery, water quality, etc. }\end{array}$ & $\begin{array}{l}\text { Best investigated through a combination of } \\
\text { remote sensing, meteorology, and combined } \\
\text { glaciological and hydrological modelling. } \\
\text { Causes and remote sensing see (2.2). }\end{array}$ & $\begin{array}{l}\text { (Huggel et al., 2003a), } \\
\text { see (2.2) and (Wagnon et } \\
\text { al., 1999) }\end{array}$ \\
\hline
\end{tabular}

physically for topographic, political and/or security reasons (Fig. 1).

- The remote location of most glacial hazard sources, the potential process interactions and chain reactions, and the far reach of some of the high-mountain hazards require remote sensing sensors capable to cover large areas at once (Fig. 1).

- Climate change induces disturbance in glacier and permafrost equilibrium and can shift hazard zones beyond historical knowledge. In addition, human settlements and activities increasingly extend towards endangered zones in many regions. As a result, historical data alone are not sufficient any more for hazard assessments and have to be combined with new observation and modelling approaches (Grove, 1987; Evans and Clague, 1994; Haeberli and Beniston, 1998; Richard- son and Reynolds, 2000; Huggel et al., 2004a; Kääb et al., 2005).

- Due to the rapid change of high-mountain environments, hazard assessments shall be undertaken routinely and regularly, combined with continuous monitoring. Remote sensing is particularly suited for both regular and rapid observation.

Recent developments in air- and spaceborne remote sensing open up new possibilities for the assessment of natural hazards in general (Mantovani et al., 1996; Sabins, 1997; Ostir et al., 2003) and glacier and permafrost related hazards in particular (Huggel, 2004; Kääb, 2004; Quincey et al., 2005). Remote sensing will therefore substantially gain importance for such works in the near future. Obstacles to the full exploitation of the remote sensing potential for high-mountain hazard assessments are of technical nature, on the one hand, but also due to the lack of expertise dissemination, on the other hand. The present contribution provides for the first 
Table 1. Continued.

\begin{tabular}{|c|c|}
\hline $\begin{array}{l}\text { Hazard } \\
\text { type }\end{array}$ & Processes \\
\hline $\begin{array}{l}\text { (3) Glacial } \\
\text { and para- } \\
\text { glacial mass } \\
\text { movements }\end{array}$ & $\begin{array}{l}\text { (3.1) Ice fall and ice avalanches } \\
\text { Ice break-offs and subsequent ice avalanches } \\
\text { from steep glaciers. In rare cases detach- } \\
\text { ment of complete glaciers. Particularly dan- } \\
\text { gerous in winter with reduced basal friction, } \\
\text { extended runout, and mass gain from snow. } \\
\text { Glacier parts can fail due to a failure of the } \\
\text { underlaying rock ( } 3.2 \text { ). Ice avalanches can } \\
\text { be triggered by earthquakes. Ice avalanches } \\
\text { can trigger lake outbursts (1.5), dam rivers } \\
\text { (1.2), transform into mud/debris flows (3.5) } \\
\text { (3.6). }\end{array}$ \\
\hline & $\begin{array}{l}\text { (3.2) Rock fall, rock avalanche } \\
\text { Glacier retreat uncovers and debuttresses } \\
\text { rock flanks. The related change in ther- } \\
\text { mal, hydrologic, hydraulic and mechanic } \\
\text { conditions can lead to rock fall and rock } \\
\text { avalanches (fast mass movement). Rock } \\
\text { avalanches can carry parts of overlaying } \\
\text { glaciers. Rock avalanches can be of in- } \\
\text { creased magnitude in glacial environments } \\
\text { (extended runout on glaciers or when com- } \\
\text { bined with ice, mass gain from ice, entrain- } \\
\text { ment of glacier parts through impact, detach- } \\
\text { ment of glaciers overlaying the rock mass } \\
\text { breaking off). Rock avalanches can be trig- } \\
\text { gered by earthquakes. }\end{array}$ \\
\hline
\end{tabular}

(3.3) Landslide/rock slide

Among other causes, glacier retreat (2.3) or slope undercutting by floods uncovers and debuttresses rock and debris flanks. The related change in hydrologic, hydraulic and mechanic conditions can lead to mass movements (slow mass movement). These can create secondary hazards such as river dams.

(3.4) Destabilisation of unconsolidated glacial deposits

Glacier retreat (2.3) leaves unprotected and unconsolidated moraine material that is prone to enhanced erosion and debris flows.

(3.5) Debris flows from glacier floods
Glacier and permafrost floods (1) are often accompanied by debris flows when erodible material is available in steep parts of the flood path. Such debris flows can show a sequence of erosion and deposition. Debris flow deposits may dam tributaries or main rivers.
Remote sensing

Detection of steep glaciers through combination of spectral data with DTM. Highresolution, -precision, and -frequency remote sensing (e.g. terrestrial close range techniques) enables sometimes monitoring of mass changes and kinematics related to entire steep glaciers or unstable sections.

\section{Selected remote sensing applications}

(Kääb, 1996; Clague and Evans, 2000; Kääb, 2000; Kääb et al., 2003c; Salzmann et al., 2004)

(Fig. 20)

\section{Mapping of rock faces and some bound- (Kääb et al., 2003c; ary conditions (e.g. glacier retreat) possible Huggel et al., 2005) through remote sensing. \\ (Figs. 1 and 2)}

$\begin{array}{ll}\text { Landslide surface characteristics, geometry } & \text { (Mantovani et al., 1996; } \\ \text { and kinematics can be monitored by repeat } & \text { Kääb, 2002; Kääb, 2004; } \\ \text { high-resolution and -precision remote sens- } & \text { Singhroy and Molch, } \\ \text { ing. } & \text { 2004) }\end{array}$

(Figs. 15 and 19)

Related zones can be detected trough remote (Huggel et al., 2004b) sensing combined with DTMs.

Remote sensing with sufficient spatial resosee (1) lution supports estimating the availability of debris in a potential flood path and its slope (i.e. disposition to erosion or deposition).

Ice cover on volcanoes and its changes (and partially also volcanic activity) can be monitored by remote sensing (see 2)
(Björnsson et al., 2001; Dean et al., 2004; Julio Miranda et al., 2005) (Fig. 23) 
Table 1. Continued.

\begin{tabular}{|c|c|c|c|}
\hline $\begin{array}{l}\text { Hazard } \\
\text { type }\end{array}$ & Processes & Remote sensing & $\begin{array}{l}\text { Selected remote sensing } \\
\text { applications }\end{array}$ \\
\hline \multirow[t]{6}{*}{$\begin{array}{l}\text { (4) Perma- } \\
\text { frost- and } \\
\text { ground ice- } \\
\text { related mass } \\
\text { movements }\end{array}$} & $\begin{array}{l}\text { (4.1) Adverse effects of permafrost creep } \\
\text { Permafrost creep (often forming rock- } \\
\text { glaciers) can inundate land and destabilise } \\
\text { or destroy constructions situated on or in it. } \\
\text { Cause: gravity-driven deformation of ice- } \\
\text { rich debris. }\end{array}$ & $\begin{array}{l}\text { Monitoring of permafrost deformation by re- } \\
\text { peat high-resolution optical remote sensing } \\
\text { and DInSAR. }\end{array}$ & $\begin{array}{l}\text { (Kääb, 2000; Kääb, } \\
\text { 2002; Kenyi and Kauf- } \\
\text { mann, 2003; Strozzi et } \\
\text { al., 2004), (Figs. } 11 \text { and } \\
\text { 18) }\end{array}$ \\
\hline & $\begin{array}{l}\text { (4.2) Thaw settlement and frost heave } \\
\text { Changes in permafrost surface geometry } \\
\text { due to changes in ground ice content from } \\
\text { ice-lense accumulation or thermokarst pro- } \\
\text { cesses. Affecting constructions; possibly } \\
\text { triggering thermokarst lakes (1.4). Thaw } \\
\text { and frost heave processes may be caused by } \\
\text { constructions (e.g. changes in snow cover } \\
\text { regime, basement heating). }\end{array}$ & $\begin{array}{l}\text { Monitoring of geometry changes from repeat } \\
\text { high-precision DTMs. }\end{array}$ & $\begin{array}{l}\text { (Kääb et al., 1997), } \\
\text { (Fig. 11) }\end{array}$ \\
\hline & $\begin{array}{l}\text { (4.3) Debris flows from permafrost } \\
\text { Permafrost thaw changes mechanic and hy- } \\
\text { drological conditions in permafrost. As a } \\
\text { consequence the disposition of periglacial } \\
\text { debris flows may increase. Temporary runoff } \\
\text { concentration (1.6) and ground saturation is, } \\
\text { thereby, often involved as trigger. }\end{array}$ & $\begin{array}{l}\text { Only detectable using remote sensing when } \\
\text { accompanied by changes in surface geome- } \\
\text { try (4.2). }\end{array}$ & $\begin{array}{l}\text { (Kääb, 1996; Hoelzle et } \\
\text { al., 1998) }\end{array}$ \\
\hline & $\begin{array}{l}\text { (4.4) Rockfall from rockglacier front } \\
\text { Advance of rockglaciers involves continu- } \\
\text { ous transport of surface debris over the rock- } \\
\text { glacier front. This may lead to local rockfall } \\
\text { endangering people and mountain infrastruc- } \\
\text { ture. }\end{array}$ & Remote sensing see (4.1) & $\begin{array}{l}\text { (Bauer et al., 2003; Kääb } \\
\text { and Reichmuth, 2005) }\end{array}$ \\
\hline & $\begin{array}{l}\text { (4.5) Destabilisation of frozen debris slopes } \\
\text { In rare cases entire sections of rockglaciers } \\
\text { or frozen debris slopes might destabilise. } \\
\text { Reasons largely unknown (dynamic, ground } \\
\text { warming, ?). Can lead to (4.1), (4.3), and } \\
(4.4) \text {. }\end{array}$ & $\begin{array}{l}\text { For slow movements detectable using high- } \\
\text { resolution remote sensing ( } 4.1 \text { and crevasse } \\
\text { formation). }\end{array}$ & $\begin{array}{l}\text { (Kaufmann and } \\
\text { Ladstädter, 2002; Roer } \\
\text { et al., 2005), (Fig. 14) }\end{array}$ \\
\hline & $\begin{array}{l}\text { (4.6) Rockfall and rock avalanches from } \\
\text { frozen rock faces } \\
\text { The thermal regime and ground ice in frozen } \\
\text { rock faces have complex thermal, mechan- } \\
\text { ical, hydraulic and hydrological effects on } \\
\text { rock stability. Related changes can cause } \\
\text { mass movements. Processes often also re- } \\
\text { lated to surface ice (3.2). }\end{array}$ & Remote sensing see (3.2). & $\begin{array}{l}\text { (Fischer, 2004; Noetzli } \\
\text { et al., 2005), (Fig. 2) }\end{array}$ \\
\hline
\end{tabular}

time a comprehensive overview of remote sensing methods available for glacier and permafrost hazard assessments in mountains. The wide range of, partially novel, application studies discussed aims at evaluating and demonstrating the potential and limits of remote sensing in the topic considered. In this way the contribution intends to elaborate present research needs, but also to contribute to the dissemination of remote sensing methods for high-mountain hazard assessment and management.

The first part of the paper concentrates on the acquisition of base data, covering a method overview (Sect. 2), image classification (Sect. 3), production of digital terrain models
(DTMs; Sect. 4), computation and analysis of terrain elevation changes (Sect. 5), and measurement of surface displacements (Sect. 6). The second part focuses on the integration of these data into hazard assessments, and on advanced analysis methods including the detection of hazard sources (Sect. 7), modelling of hazard potentials (Sect. 8), and disaster management (Sect. 9). Conclusions and perspectives finalize this overview article. 

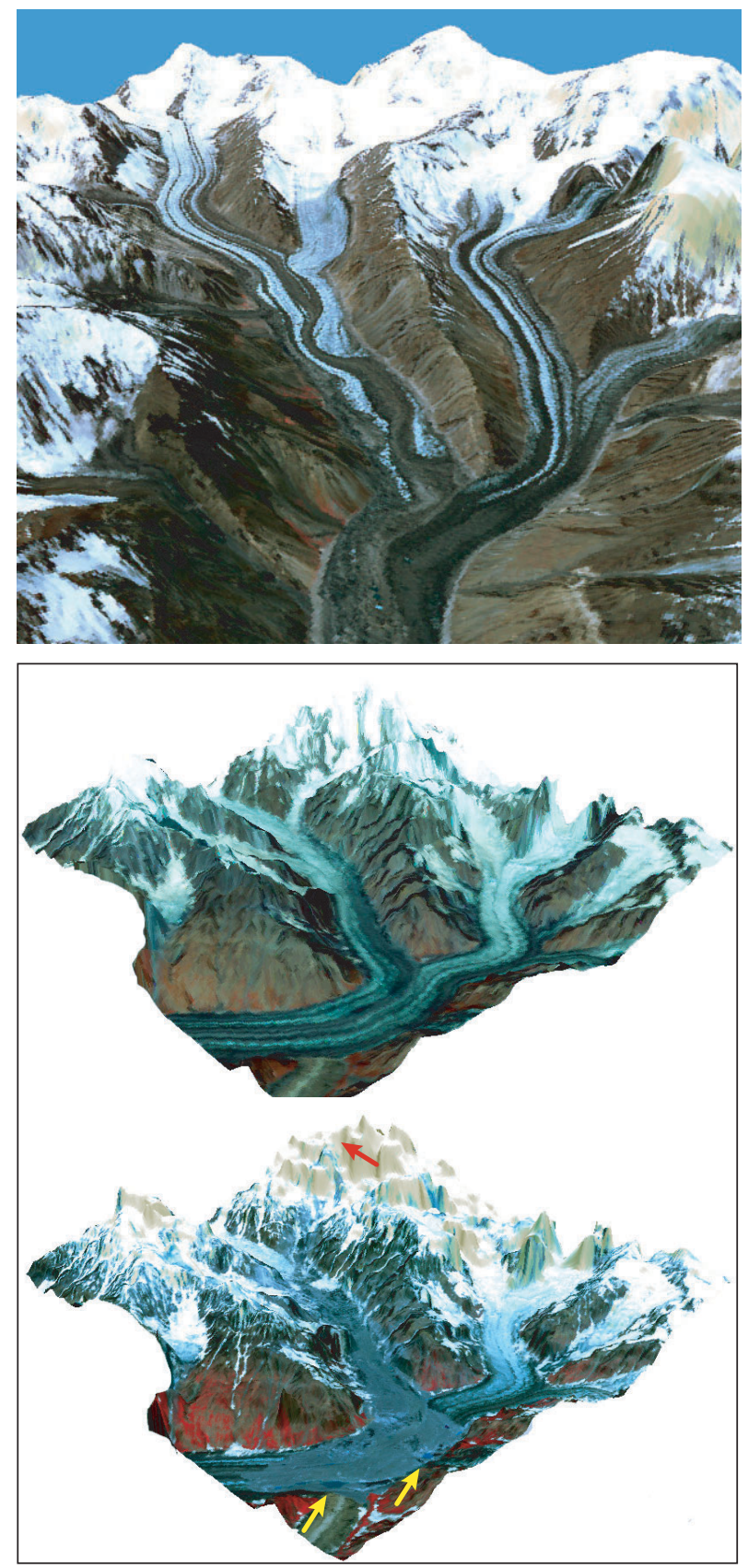

Fig. 1. Synthetic oblique views computed from sections of ASTER satellite scenes draped over ASTER-derived DTMs. Upper panel: area at the Pik Ismail Somoni in the Tajik Pamirs with a typical surge-type-glacier as indicated by deformed ("looped") moraines (Lat.:39.9 $9^{\circ} \mathrm{N}$, Lon.: $72.1^{\circ} \mathrm{E}$; terrain section shown roughly $15 \times 15 \mathrm{~km}$ ). Lower panel: rock/ice-avalanche event in the Tajik Pamirs from around spring $2002\left(38.8^{\circ} \mathrm{N}, 71.9^{\circ} \mathrm{E}\right.$; terrain section shown roughly $10 \times 10 \mathrm{~km})$. The upper image is Landsat ETM+ data from 2000, the lower is ASTER data from 2003. The red arrow points to the approximate source zone of the avalanche, the yellow arrows point to lakes dammed by the avalanche deposits. The avalanche deposits cover an area of roughly $6 \times 10^{6} \mathrm{~m}^{2}$, horizontal runout distance is roughly $10 \mathrm{~km}$, and vertical drop roughly $2000 \mathrm{~m}$ (overall slope roughly $11^{\circ}$ ).

\section{Method overview}

\subsection{Important factors}

The applicability of remote sensing for high-mountain hazard assessments is predominantly governed by the following factors:

- The "spatial resolution" of the sensor decides about the degree of detail that can be detected from the data. Often, fine resolution is required to assess important parameters of glacier- and permafrost hazards (e.g. discrimination of debris versus rock surface). In order to characterise spatial resolution, we use here the terms high resolution $(<5 \mathrm{~m})$ and medium resolution $(5-100 \mathrm{~m})$. Low (100-1000 m) and very-low resolution systems $(>1000 \mathrm{~m})$ are not covered in this overview.

- The "spatial coverage", i.e. the ground area or width of the ground track sensed is roughly related to the spatial resolution of the sensor through technical constraints e.g. concerning detectable level of incoming signal strength (sensor noise-level), or onboard-recording and down-link capacities. While, for instance, mediumresolution Landsat, IRS, or ASTER data are very useful for first-order regional-scale hazard assessments, highresolution IKONOS, QuickBird, or Orbview data are preferable for detailed local-scale investigations. SPOT5 data (up to $2.5 \mathrm{~m}$ resolution, $60 \mathrm{~km}$ scene width) combine both advantages to some extent.

- The "temporal resolution", i.e. revisit time of the remote sensing system has to be in agreement with the rate of hazard development, or the changes observed. The temporal resolution of a system is among others connected to its spatial coverage, and to the pointability of the sensor, e.g. how far the sensor can be rotated in cross-track direction in order to cover areas far off the ground-projected track. As an example, the ASTER visible and near infrared (VNIR) instrument can be pointed up to $\pm 24^{\circ}$ allowing for repeat imaging as frequently as every two days (and better in high latitudes) for urgent priorities. For instance, annual resolution might be sufficient to monitor the development of proglacial lakes, whereas repeat times of a few days are required for disaster management in connection with ice-avalanche or landslide induced temporary lakes.

- The "timing" of data acquisition has to be under control of the user, or to coincide with the user needs by chance. The probability for the latter increases with temporal resolution. Timing is of particular importance when remote sensing data are required at a given repeat cycle (e.g. early warning, seasonal restrictions) or when rapid response is needed (e.g. search and rescue operations, disaster management).

- The "section of the electromagnetic spectrum" available determines among others the surface parameters that are 
recorded at the sensor and the dependence of the sensor to weather and illumination conditions (e.g. all-weather and night-time capability of microwave sensors, nighttime capability of thermal infrared (TIR) sensors).

- "Stereo, interferometric or ranging capability" of the remote sensing system enables the computation of terrain elevations, often a crucial prerequisite for the analysis of high-mountain environments in the absence of appropriate topographic maps.

- "Usability of data" for the user, with the respect to e.g. existence and access to data archives, speed of ondemand acquisition, speed of delivery, simplicity of data formats and size, financial resources as well as hard- and software resources, and processing and analysis knowledge of the user.

\subsection{Airborne remote sensing}

Airborne remote sensing technologies that are applicable for high-mountain hazard assessments include the following techniques (Fig. 2):

- Hard-copy or digital aero-photogrammetry based on frame imagery or linear array CCD sensors are well established techniques for generation of digital terrain models (DTMs), detection of vertical terrain changes, measurement of terrain displacements, and detailed interpretation (Baltsavias et al., 1996; Hauber et al., 2000; Kääb, 2000, 2002; Kaufmann and Ladstädter, 2002; Miranda and Granados, 2003).

- Whereas modern digital air cameras have also multispectral capabilities by including a few bands in the visible and near infrared (VNIR), there are also some hyperspectral sensors available with tens to hundreds of narrow bands in the VNIR and SWIR (short-wave infrared) spectrum. Airborne hyperspectral remote sensing allows for detailed spectral analysis of the ground surface (e.g. lithology, vegetation, lake water) (e.g. Keller et al., 1998), but is so far little applied directly for mountain hazard assessments due to the high data acquisition costs and the large expertise required for data analysis. As yet the method is subject to scientific research rather than available on an operational level.

- Airborne laserscanning is an upcoming and highly promising tool for acquiring high-resolution DTMs (Baltsavias et al., 2001; Geist et al., 2003; Janeras et al., 2004). From repeat DTMs it is also possible to derive terrain displacements. Some laserscanning instruments are able to record the signal intensity and, thus, to include spectral terrain characteristics (Lutz et al., 2003).

- Airborne synthetic aperture radar (SAR) is rarely used in high-mountains, mainly due to topographic restrictions. The applied microwave spectrum, however, bears

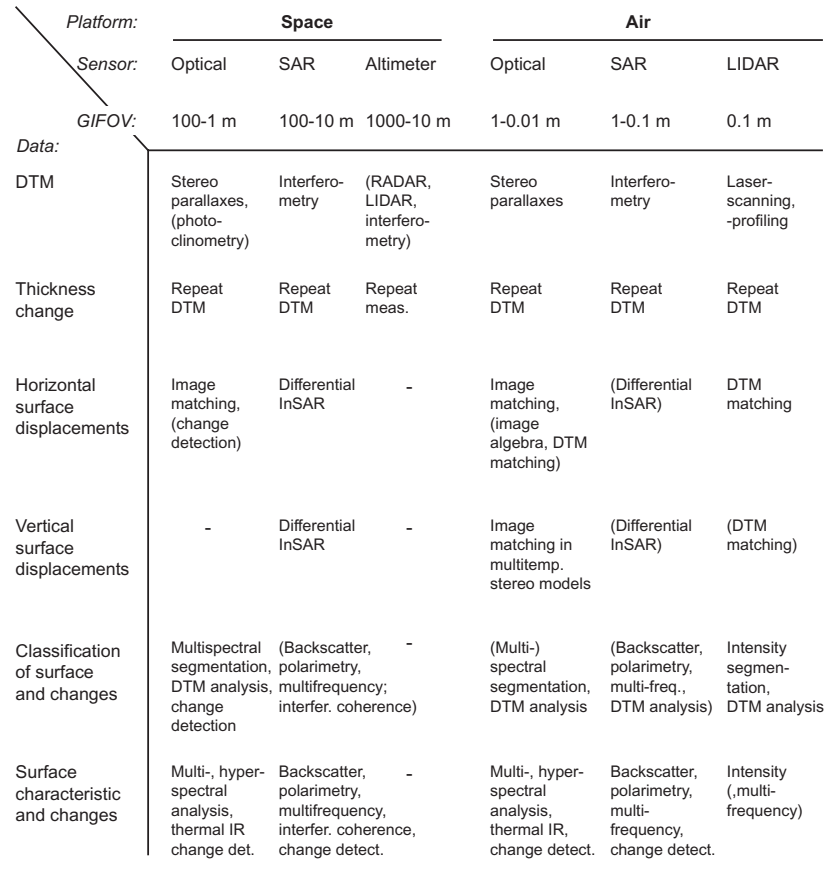

Fig. 2. Overview of remote sensing methods suitable for highmountain hazard assessment, in relation to platforms and sensors, and data types to be derived. Abbreviations: DTM: digital terrain model; GIFOV: ground-projected instantaneous field of view (i.e. spatial sensor resolution); IR: infrared; LIDAR: light detection and ranging (laserscanning); SAR: synthetic aperture radar; InSAR: interferometric SAR.

a high potential due to its all-weather and day/night capability, and for extracting surface and sub-surface characteristics that influence the complex di-electrical constant of the ground (e.g. roughness, humidity) (Vachon et al., 1996; Stevens et al., 2003).

Airborne remote sensing campaigns in mountains cover usually of a few or a few tens of $\mathrm{km}^{2}$ by one scene/image. Data costs range from a few EUR/ $/ \mathrm{km}^{2}$ for reproduction of existing data to hundreds of EUR $/ \mathrm{km}^{2}$ for original acquisitions. Beside many advantages of airborne remote sensing such as level of detail and direct customer control, this class of platforms is often not applicable for areas where major topographic, political, security or financial restrictions are involved. Satellite sensors overcome these restrictions in parts. They are able to cover large areas without ground access needed, data are comparably cheap and well accessible, and for some sensors a repeat cycle of a few days is possible (Gao and Liu, 2001; Huggel, 2004; Kääb, 2004).

\subsection{Spaceborne remote sensing}

Spaceborne remote sensing technologies suitable for highmountain hazard assessments include the following techniques (Fig. 2):

- Optical multispectral spaceborne imaging represents a well-established satellite remote sensing method for 


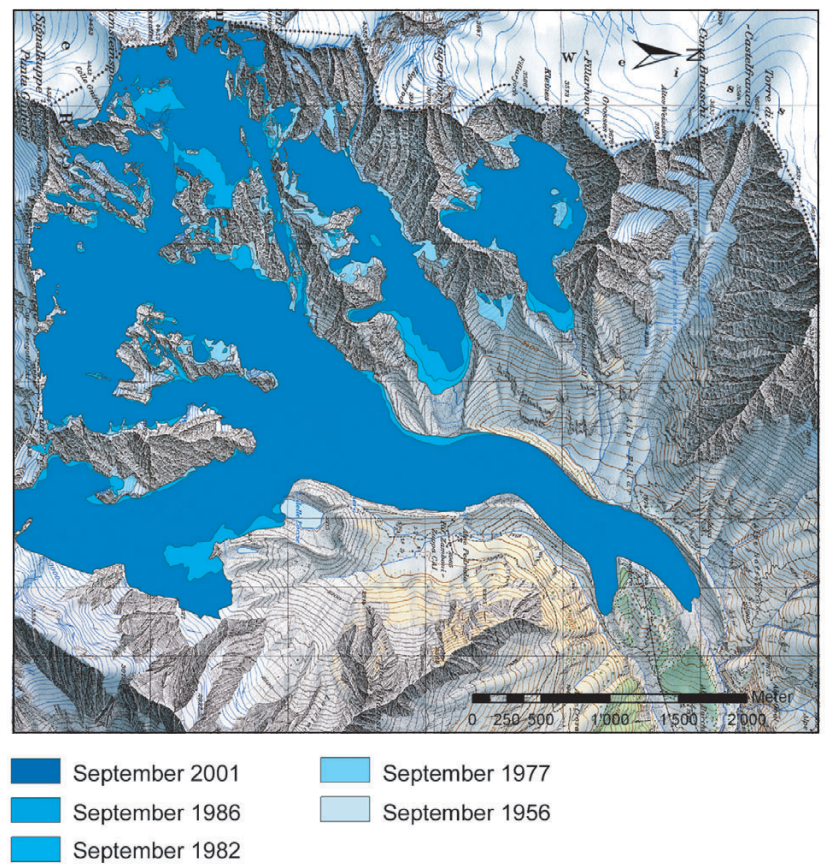

Fig. 3. Changes in glacier extent in the Monte Rosa east face $\left(45.9^{\circ} \mathrm{N}, 7.9^{\circ} \mathrm{E}\right)$ as derived from orthophotos between 1956 (light blue) and 2001 (dark blue). In the recently de-glaciated zones drastic mechanical, thermal, hydraulic and hydrological changes affect the frozen and unfrozen rock and debris deposits, and cause increased rock fall activity. Background: topographic map, sheet Zermatt, by Swisstopo, permission BA046472.

mapping and monitoring ground cover and its changes. It is often used for detecting hazard source areas and terrain changes, and for mapping of endangered zones (Buchroithner et al., 1982; Kääb et al., 2000, 2003c; Huggel et al., 2002, 2004c; Liu et al., 2005; Silverio and Jaquet, 2005).

- Satellite optical stereo, usually combined with multispectral imaging, enables the computation of DTMs, a crucial prerequisite for most high-mountain studies (Toutin, 2001; Gamache, 2004; Kääb, 2004).

- Interferometric SAR (InSAR) from space can also be used to derive DTMs. In particular useful for supporting hazard assessments in remote areas is the DTM from the single pass InSAR campaign Shuttle Radar Topography Mission (SRTM). Repeat InSAR can further be applied to measure terrain movement (e.g. differential InSAR, DInSAR) (Gens and van Genderen, 1996; Mantovani et al., 1996; Rignot et al., 1996; Kelley et al., 1997; Moorman and Vachon, 1998; Toutin and Gray, 2000; Strozzi et al., 2004). In addition, the microwave backscatter (i.e. the intensity of the return-signal recorded at the sensor), the interferometric phase coherence, and the signal (de-)polarisation can be analysed (Coltelli et al., 1996) (see Sect. 3).
Spaceborne remote sensing data of medium resolution cover up to tenthousands of $\mathrm{km}^{2}$ by one scene. Data costs are on the order of few EUR $/ \mathrm{km}^{2}$ or much less.

Here, we do not cover terrestrial remote sensing methods since the focus of our contribution is on remote areas. However, it should be stressed that, for instance, terrestrial photogrammetry (Brecher and Thompson, 1993; Kaufmann and Ladstädter, 2004; Pitkänen and Kajutti, 2004), touch-less laser rangers, terrestrial laser scanning (Bauer et al., 2003; Janeras et al., 2004) and terrestrial SAR (Tarchi et al., 2003) can be highly valuable techniques for detailed monitoring tasks.

\section{Image classification}

The most common application of remotely sensed image data for high-mountain hazard assessment consists in the interpretation and classification of the image content. Thereby, both the spectral image information and the spatial context of such information are exploited. The technologically simplest form of image analysis (though by no means the least important and easiest analysis!) is the manual mapping of features of interest from the imagery available (Fig. 3). In particular under conditions of difficult topography and weak optical contrast, or for highly complex assessment tasks, manual image segmentation might be superior to semiautomatic and automatic techniques. A number of image enhancement and fusion techniques are available to facilitate manual interpretation (Lillesand and Kieffer, 2000).

However, for rapid, repeated, and/or large-area quantitative applications, automatic image classification is able to offer valuable support. The large variety of available techniques ranges from mono-spectral (i.e. grey-value) segmentations, multi- and hyperspectral classifications, to spatio-spectral analyses utilising not only the spectral information of the image pixels but also their spatial context (Schowengerdt, 1997; Lillesand and Kieffer, 2000; Kääb, 2004).

For instance, glacierized areas (Hall et al., 1989; Aniya et al., 1996; Kääb et al., 2000, 2003a; Albert, 2002; Paul, 2002; Paul et al., 2002, 2004b; Salzmann et al., 2004) or glacier lakes (Huggel et al., 2002; Wessels et al., 2002) can be mapped automatically. Archived data sets are an invaluable source for comparison between past and present situations (Fig. 4) (Kääb and Haeberli, 2001; Kääb et al., 2003c; Silverio and Jaquet, 2005).

Mountain permafrost, a purely thermal phenomenon, can hardly be remotely sensed in a direct way, but related indicators such as rockglaciers, thaw lakes, polygones, etc. can be detectable in remote sensing data (e.g. Lewkowicz and Duguay, 1999; Frauenfelder et al., 2005).

Many glacier- and permafrost-related hazards are connected to terrain changes. Thus, multitemporal applications are of particular interest for assessing high-mountain hazards. Beside the measurement of elevation changes and terrain displacements as discussed in the following sections, a 


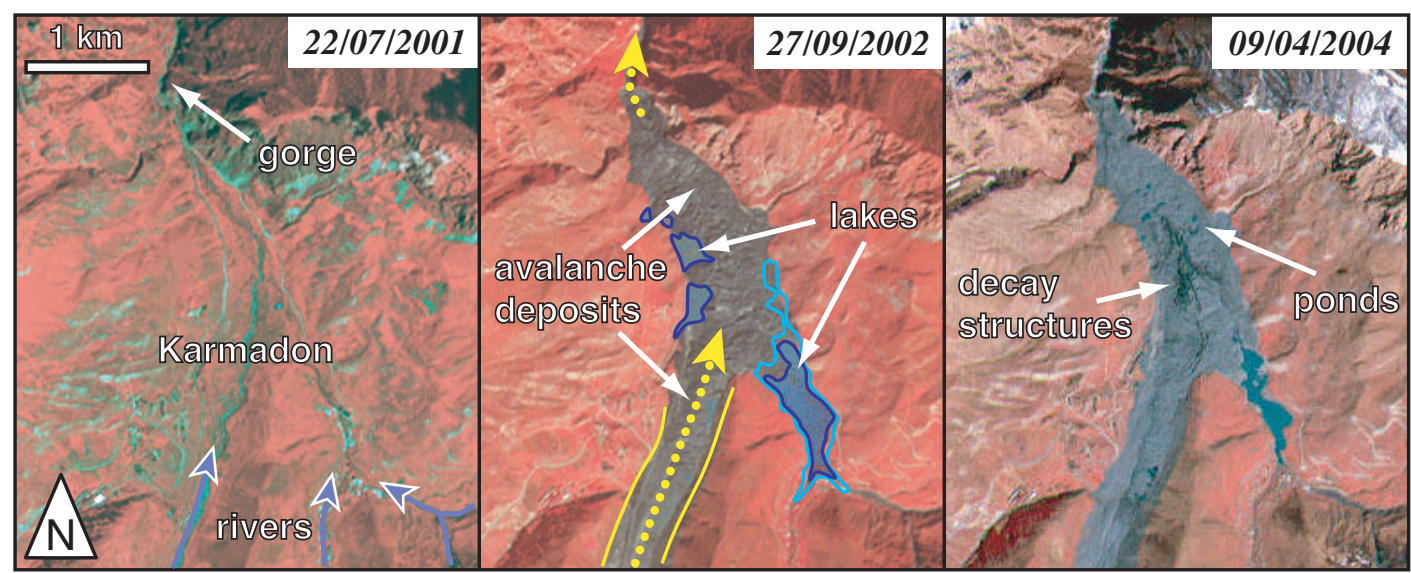

Fig. 4. ASTER false colour imagery of the Karmadon area from before (left) and after (middle and right) the 20 September 2002 Kolka/Karmadon rock-ice avalanche disaster, North Ossetia, Caucasus $\left(42.8^{\circ} \mathrm{N}, 44.5^{\circ} \mathrm{E}\right)$. During this event, a rock-ice avalanche of several million $\mathrm{m}^{3}$ from the north face of the Kazbek massif sheared off the entire Kolka glacier tongue. This combined avalanche rushed $18 \mathrm{~km}$ down the Genaldon valley. Approximately 100 million $\mathrm{m}^{3}$ of ice and debris were deposited near the village of Karmadon where the avalanche was stopped by a narrow gorge (Kääb et al., 2003c; Kotlyakov et al., 2004; Haeberli et al., 2005; Huggel et al., 2005). The rivers in the area (blue arrows) were dammed by the avalanche deposits and formed lakes (dark blue line: lake extent as of 27 September 2002; light blue line: lake extent as of 22 October 2002). On the 9 April 2004 image, the rock-ice dam showed already distinct melt and decay structures.

group of change detection techniques are applied. Related strategies include (Schowengerdt, 1997; Kääb, 2004):

- "multitemporal data overlay and comparison", i.e. interpretation of change after individual classifications, where the results from monotemporal image classifications are superimposed (e.g. lakes in Fig. 4, middle panel).

- "animation", where repeat images or derived classifications are shown sequentially (so-called "flickering") (Kääb et al., 2003b).

- "multitemporal false colour composites" (FCC), where the individual channels of a colour image (e.g. red, green, blue) are composed by images of different acquisition times. Thereby, radiometric changes between the acquisition times lead to the emphasis or attenuation of individual colour channels in the multitemporal FCC with respect to the unchanged terrain sections. As a result, changes can become visible as "unnatural" colours (Fig. 5) (Ostir et al., 2003; Kääb, 2004).

- "image algebra", (also called band math, or algebraic expressions), where a change image is computed from two or more multitemporal input images through algebraic band operations such as band ratios or normalised differences (Schowengerdt, 1997; Huggel et al., 2002; Kääb, 2004, 2005; Paul and Kääb, 2004). For instance, for a multitemporal band ratio ((channel $\mathrm{X}$ of image at time 1)/(channel $\mathrm{X}$ of image at time 2)) changed image sections are indicated by ratio values far off the value 1 .

- "multitemporal principle component transformation". A principle component transformation (PCT) computes

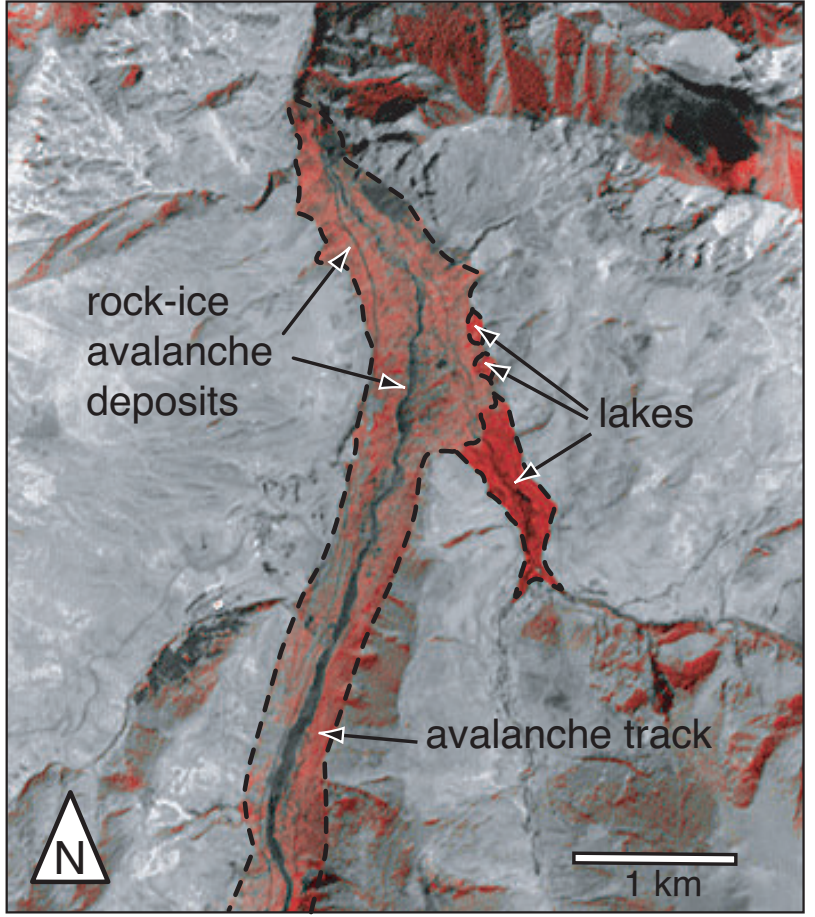

Fig. 5. Deposits of the Kolka/Karmadon rock-ice avalanche (see Fig. 4). Change detection is done by a multitemporal RGBcomposite. Red: ASTER band 3 of 22 July 2001; green and blue: ASTER band 3 of 13 October 2002. The dashed outline marks the avalanche path running from south to north, the deposits in front of the gorge at the upper edge of the image, and the lakes, which were dammed by the avalanche deposits. Red-coloured changes in northern slopes are due to different shadow/illumination conditions between the acquisition dates. 


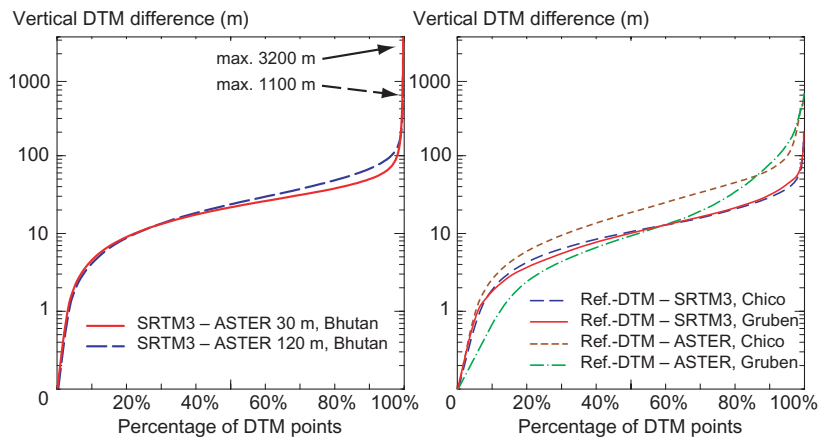

Fig. 6. Cumulative histograms of vertical differences between SRTM3, ASTER and aerophotogrammetric DTMs for a study site in Bhutan (left panel), and Gruben, Swiss Alps, and Glaciar Chico, Chile (right panel). (Bhutan $30 \mathrm{~m}: 100 \%=201000$ points; Gruben ASTER: $100 \%=37100$ points; Gruben SRTM: $100 \%=4760$ points; Chico ASTER: 100\%=71 700 points; Chico SRTM: 100\%=29000 points).

a new colour space for a multi-channel image in a way that the individual channels of the new, transformed image are sorted according to the spatial image variability they contain. Thus, the first principle component(s) computed from a multitemporal image data set tend to indicate the largest radiometric changes between the images (Schowengerdt, 1997). Multitemporal PCT can be useful for sets of many repeat data where FCCs or simple image algebra fail, e.g. for long time-series such as from the Landsat instrument series.

- "change vector analysis", and "change axis analysis", where the digital numbers (DNs) of the same or different channels of multitemporal image data are plotted against each other in scatter plots and compared (Schowengerdt, 1997; Kääb, 2004). Thereby, certain radiometric changes appear as different change-patterns in the scatter plots, and according change-pixels can be re-identified and marked in the multitemporal images. These techniques are heavily affected by illumination differences between the acquisition dates and thus seldom used in mountains.

- "multitemporal classifications", where repeat data sets are included in a combined classification scheme and the "change classes" and "non-change classes" (e.g. iceto-rock, debris-to-vegetated, ice-to-water) are derived automatically or through training areas.

These techniques work both on optical and SAR data. In the microwave spectrum, analysis of the backscatter, the coherence of the SAR interferometric phase, and the signal polarisation is able to support delineation and characterisation of the terrain surface and its dynamic (Coltelli et al., 1996; Engeset and Weydahl, 1998; Friedman et al., 1999; Floricioiu and Rott, 2001). Analysis of the microwave backscatter is, however, seldom used in the context of high-mountain hazards due to the complex electromagnetic nature of the ground reflection and topographicallyand sensor-induced geometric problems such as layover and radar shadow (Coltelli et al., 1996). Beside the backscatter amplitude, also interferometric coherence or its spatiotemporal changes (Weydahl, 2001) can be exploited. For instance, interferometric coherence points to stable terrain, whereas its loss over time may hint to changes in surface conditions such as from terrain destruction (cf. Fig. 18). Furthermore, the signal (de-)polarisation can be analysed (Stebler et al., 2002). If a clear polarisation or depolarisation in the backscatter signal from a polarimetric SAR system can be observed for a certain terrain section, certain surface characteristics can be inferred (e.g. a blocky surface acting as corner reflectors).

Particularly promising for hazard assessment and disaster management is the (multitemporal) fusion of optical and SAR data because it is able to combine the advantages of different sections of the electromagnetic spectrum (Ostir et al., 2003). In that way, for instance, SAR data can bridge gaps in optical time series due to cloud cover. Snow humidity conditions, that are hardly detectable from optical sensors alone, can be inferred from SAR data in snow mapping (Rott and Strobl, 1992; Rott, 1994; König et al., 2001).

Accurate co-registration of the repeat data, i.e. identical ground coordinates for identical (stable) terrain points, is a mandatory prerequisite of any change detection procedure.

\section{Digital terrain models}

\subsection{Satellite stereo}

DTMs represent the core of any investigation of highmountain hazards, because many high-mountain geomorphologic processes are driven by the relief energy. Furthermore, DTMs are needed for orthorectification of image data, and thus for accurate georeferencing and co-registration with other or repeat data. An efficient spaceborne way to generate such DTMs for nearly any place on the Earth is satellite along-track stereo from sensors such as JERS, ASTER or SPOT-5. For mountain environments with rapidly changing surface conditions such as snow-cover, along-track stereo (acquired within minutes during one overflight) is preferable to cross-track stereo that utilises imagery from neighbouring tracks, sometimes with a temporal baseline of weeks or months (Ehlers and Welch, 1987). DTMs can be produced for mountain terrain through digital photogrammetric methods with a vertical accuracy approaching the pixel size of the applied sensor (e.g. $15 \mathrm{~m}$ for ASTER; Fig. 6) and with typical horizontal grid spacings equivalent to $2-4$ image pixels in size (Al-Rousan and Petrie, 1998; Bishop et al., 2000; Toutin, 2001; Kääb, 2002, 2005; Toutin, 2002; Zomer et al., 2002; Hirano et al., 2003; Kääb et al., 2003a; Berthier et al., 2004; Gamache, 2004; Stevens et al., 2004; Cuartero et al., 2005, Kamp, 2005 \#1826; Eckert et al., 2005). 

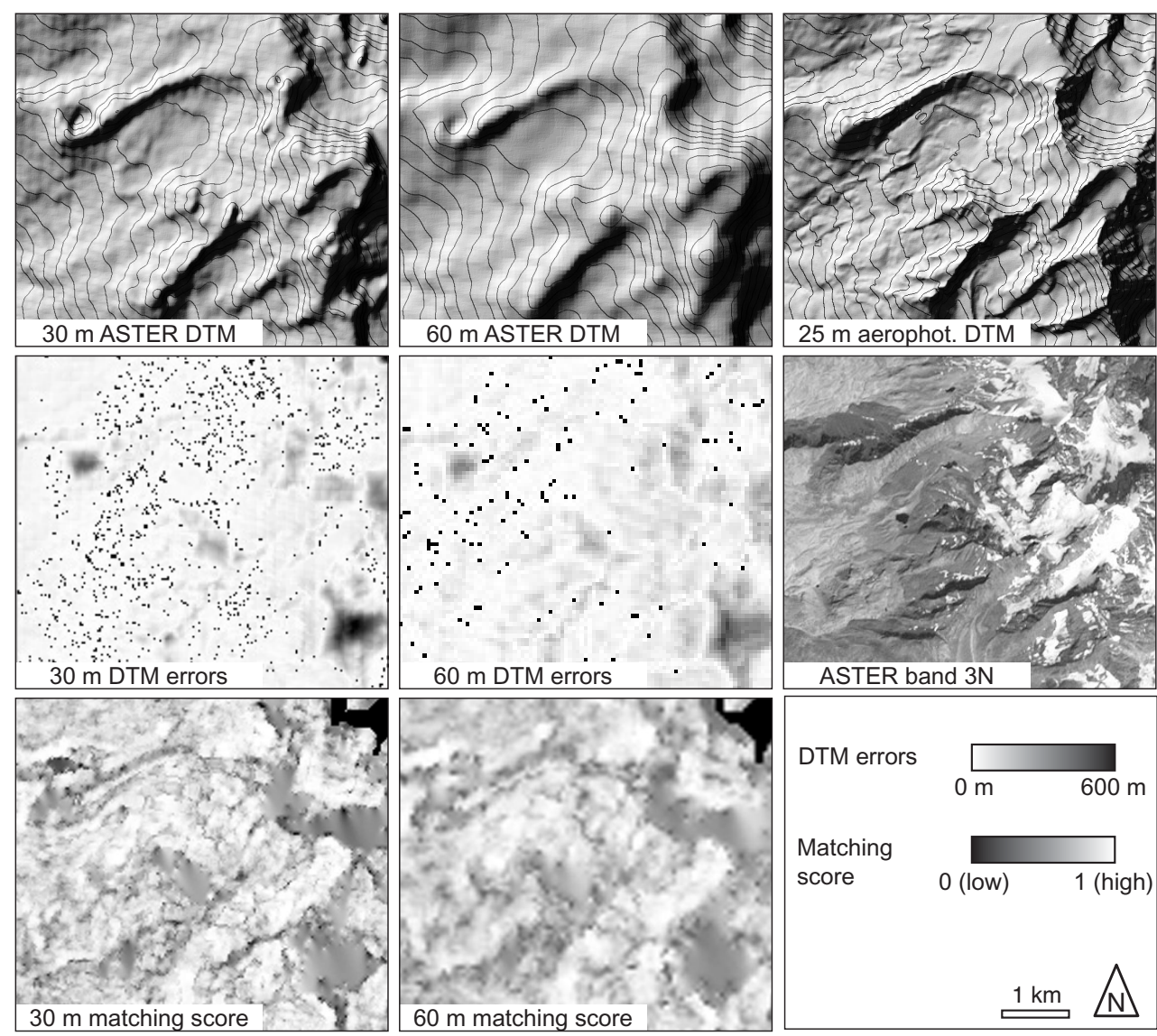

Fig. 7. Gruben area, Swiss Alps (46.2 $\left.{ }^{\circ} \mathrm{N}, 7.9^{\circ} \mathrm{E}\right)$. First row: $30 \mathrm{~m}$ ASTER DTM (left), $60 \mathrm{~m}$ ASTER DTM (middle), aerophotogrammetric DTM (right). Contour interval is $100 \mathrm{~m}$. Second row: Grayscale-coded vertical DTM differences between the aerophotogrammetric DTM and the ASTER DTMs of first row (left and middle). Right: ASTER nadir band 3N orthoimage for better location of DTM errors and matching correlation. Third row: score channels of DTM matching correlation. The darker the pixel the worse the correlation. Severe vertical DTM errors and matching problems are more pronounced for the $30 \mathrm{~m}$ ASTER DTM, which on the other hand shows more terrain details.

However, large errors in DTMs derived from optical satellite stereo can occur due to the following reasons:

- steep flanks facing away from the oblique stereo sensor (e.g. northern slopes are strongly distorted or even hidden in the back-looking stereo channel for the descending ASTER),

- particularly rough topography with sharp peaks, that are too small to be clearly matched in both stereo partners, and/or

- insufficient optical contrast (e.g. snow cover).

In such cases, the stereo parallaxes required for DTM generation can be matched at different image resolutions and/or using different image chip sizes. Coarser image resolutions and larger matching chip sizes tend to produce more robust but less detailed DTMs (Figs. 6 and 7). Potential DTM errors can then be detected from analysing the vertical deviations between the different DTMs, and erroneous zones can be filled by interpolation or using data from the coarser
DTM levels (Zollinger, 2003; Kääb, 2004, 2005; Kääb et al., 2004b; Weidmann, 2004). In addition, filters can be constructed to eliminate errors formed as sharp spikes and holes in DTMs. Such errors can be detected as exceptionally large elevation differences over short distances, and related large gradients and curvatures in the DTM (Zollinger, 2003; Eckert et al., 2005).

Often, DTM errors are accompanied by low correlation values from the stereo-parallax matching procedure between the stereo image partners and can thus be identified using a so-called matching score-channel of the DTM (Fig. 7). Where this channel indicates weak correlation between the stereo image partners involved in the computation of an individual elevation value, the according DTM points can be eliminated or filtered (Weidmann, 2004). The procedure can be combined with the above error detection from DTMs generated at different resolutions.

A further simple and efficient method for evaluating DTMs and detecting severe errors is to produce multiple orthoimages using the same DTM but source images from different positions such as the stereo partners from along-track 


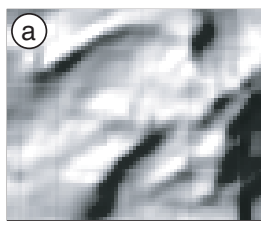

ASTER

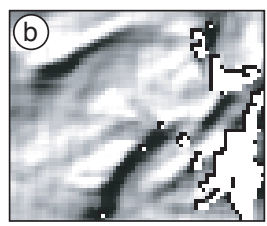
SRTM

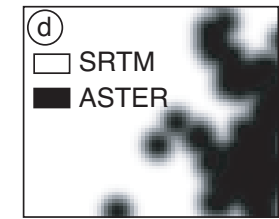

Weights for fusion Aerophotogrammetry

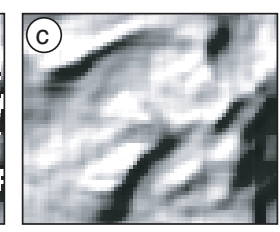

ASTER-SRTM fusion

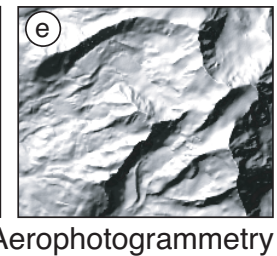

Fig. 8. Fusion between a DTM from ASTER stereo and SRTM. (a) hillshade of an ASTER DTM of the Gruben area, Swiss Alps, derived at $60 \mathrm{~m}$ resolution; (b) SRTM DTM with data gaps in white; (c) fusion between both DTMs; (d) fusion weights for filling the SRTM gaps with ASTER DTM data (white: SRTM is used, black: ASTER is used; grey: weight of SRTM elevation values with respect to ASTER DTM); (e) aerophotogrammetric DTM for comparison.

stereo. Thereby, vertical DTM errors translate into horizontal distortions, which become different for different incidence angles and can thus be easily visualised by animated overlay or other change detection techniques between the different orthoimages (Kääb, 2004, 2005).

DTMs from satellite stereo show characteristics such as data gaps, accuracy, etc., that are in parts different from the characteristics of InSAR-derived DTMs. It can, therefore, be of particular interest to merge DTMs from satellite stereo with DTMs from satellite InSAR, namely the SRTM DTM, in order to combine the advantages of both sensor types. Such DTM-fusion helps especially in finding severe vertical and horizontal DTM errors, and filling data gaps in either of the DTMs to be fused. DTM-merging techniques range from replacement of data (Kääb, 2005), weighted fusion resulting in smooth transitions between DTMs (Fig. 8) (Weidmann, 2004), to merging in support of the DTM processing itself (e.g. DTM-approximation in order to geometrically constrain stereo parallax matching or interferometric phase unwrapping) (Honikel, 2002).

Photoclinometry, i.e. the inversion of terrain shading to derive terrain geometry (also called "shade-to-shape" or "shape from shading") is hardly useful for mountain hazard studies because a constant reflectivity over the terrain is necessary in order to attribute changes in reflection to terrain slope and aspect alone (Bindschadler and Vornberger, 2000). Therefore, the technique has been applied to ice sheets.

An important processing step before merging or comparing multi-source DTMs is to ensure accurate co-registration of the multiple data sets. If the original sensor model and orientation is inaccessible, cross-correlation and according transformations between the DTMs to be compared, or between products derived thereof (e.g. orthoimages) is recom- mended (for more details see below section on elevation changes).

\subsection{Radar interferometry; Shuttle Radar Topography Mis- sion}

Sensors in the microwave spectrum are able to overcome limitations connected to optical sensors, namely the weather and sunlight dependency. Interferometric synthetic aperture radar (InSAR) is used to generate DTMs (Renouard et al., 1995; Toutin and Gray, 2000; Crosetto, 2002). DTMs from spaceborne repeat-pass interferometry such as from ENVISAT, ERS-1/2, or Radarsat reach a vertical accuracy in the order of metres and a spatial resolution of tens of metres (Renouard et al., 1995; Sties et al., 2000; Crosetto, 2002; Stevens et al., 2003; Strozzi et al., 2003b).

A particularly interesting campaign is the single-pass Shuttle Radar Topography Mission (SRTM) of February 2000, which produced DTMs with about $30 \mathrm{~m}$ (1 arc-second, SRTM1) and $90 \mathrm{~m}$ (3 arc-seconds, SRTM3) grid size, and with a vertical accuracy of a few meters to decameters (Fig. 6) (Rabus et al., 2003; Rignot et al., 2003; Stevens et al., 2003; Kääb, 2005). The SRTM covered the continents between $60^{\circ} \mathrm{N}$ and $54^{\circ} \mathrm{S}$. Where available, the SRTM indeed represents a revolutionary data set for all kinds of terrain studies, in particular also for high-mountain hazard assessments. However, due to radar shadow, foreshortening, layover and insufficient interferometric coherence, the SRTM DTM has significant voids in high mountains (Fig. 8). In such cases, we regard the fusion between spaceborne photogrammetric DTMs and the SRTM DTM as a promising approach (see previous section on satellite stereo; Fig. 8).

The spatial resolution of airborne SAR DTMs is in the order of metres or even less, and their vertical accuracy for mountainous terrain lies in the order of decimetres to metres, both depending on the wavelength applied. Current systems (e.g. AeS-1, GeoSAR, TOPSAR) use X- to P-band SAR (i.e. around 3 to $80 \mathrm{~cm}$ wavelength) (Vachon et al., 1996; Stevens et al., 2003; Stebler et al., 2004). Airborne InSAR sensors usually apply single-pass interferometry. However, multiple overflights with different azimuths may be required to overcome limitations from radar shadow or layover.

\subsection{Aerial photogrammetry}

Airborne photogrammetry applies similar techniques compared to the spaceborne optical methods, though with higher accuracy due to the better spatial image resolution generally available. The method is still, in most cases, based on analogue (i.e. hard-copy) airphotos (Kääb, 2000). Digital photogrammetry based on digitised hard-copy images or digital imagery enables automatic DTM and orthoimage generation (Chandler, 1999; Hauber et al., 2000; Kääb and Vollmer, 2000; Zhang and Grün, 2004). Related DTMs have, depending on the image scale and pixel size, a vertical accuracy on the order of centimetres to metres, and a spatial resolution 
on the order of metres to decametres (Baltsavias et al., 1996; Kääb and Vollmer, 2000; Mora et al., 2003).

Aerial photogrammetry is a particularly important tool in view of the existing archives of analogue airphotos, which represent an invaluable source to quantitatively compare temporal evolutions (Fox and Nuttall, 1997; Kääb and Vollmer, 2000; Weber and Herrmann, 2000; Haeberli et al., 2001; Kääb and Haeberli, 2001; Julio Miranda et al., 2005). Although most aerial photographs are taken in an analogue way, digital frame or linear array cameras are increasingly applied (Hauber et al., 2000; Grün and Zhang, 2002; Roer et al., 2005). Due to the large technical knowledge and special equipment needed to handle airborne digital imaging, it is difficult to use this technique worldwide, so far. However, the possibility from digital imaging to generate DTMs and orthophotos nearly in real-time (literally "on the flight") has, in theory, an important advantage in disaster management and response.

\subsection{Laserscanning (airborne LIDAR)}

DTM accuracy similar to the one of airborne photogrammetry can be obtained from airborne laserscanning (or light detection and ranging, LIDAR) - a promising technique in particular for glacier and permafrost monitoring (Favey et al., 1999; Baltsavias et al., 2001; Geist et al., 2003; Lutz et al., 2003; Janeras et al., 2004). In terms of flight conditions required, laserscanning is comparable to aerophotogrammetry. As an active sensor it provides also good results over snow cover, where photogrammetric methods fail due to the lack of optical contrast. DTMs from laserscanning have a spatial resolution on the order of meters. The resulting high degree of terrain details represented enables new methods of geomorphometric terrain analysis as well as terrain dynamics analysis. If available - what will be rarely the case in remote areas, though - laserscanning is a method, which should be considered whenever accurate DTMs and elevation changes are required for hazard assessments and disaster management. Airborne laserscanners are increasingly able to record the signal intensity (Lutz et al., 2003) or are equipped with electro-optical imaging devices, too, enabling combined analyses.

\section{Terrain elevation changes (DTM differences)}

Terrain elevation changes over time, i.e. vertical differences between repeat DTMs, are indicators for glacial and geomorphodynamic processes such as glacier fluctuations and mass movements. Thus, their detection can be an important step of high-mountain hazard assessment and disaster mapping (Kääb, 1996, 2000).

In general, changes in terrain elevation are derived by subtracting repeat DTMs. The accuracy of such-derived vertical changes is, in principle, on the order of the accuracy of the repeat DTMs that are used. If the DTMs compared represent independent measurements, the root mean square error

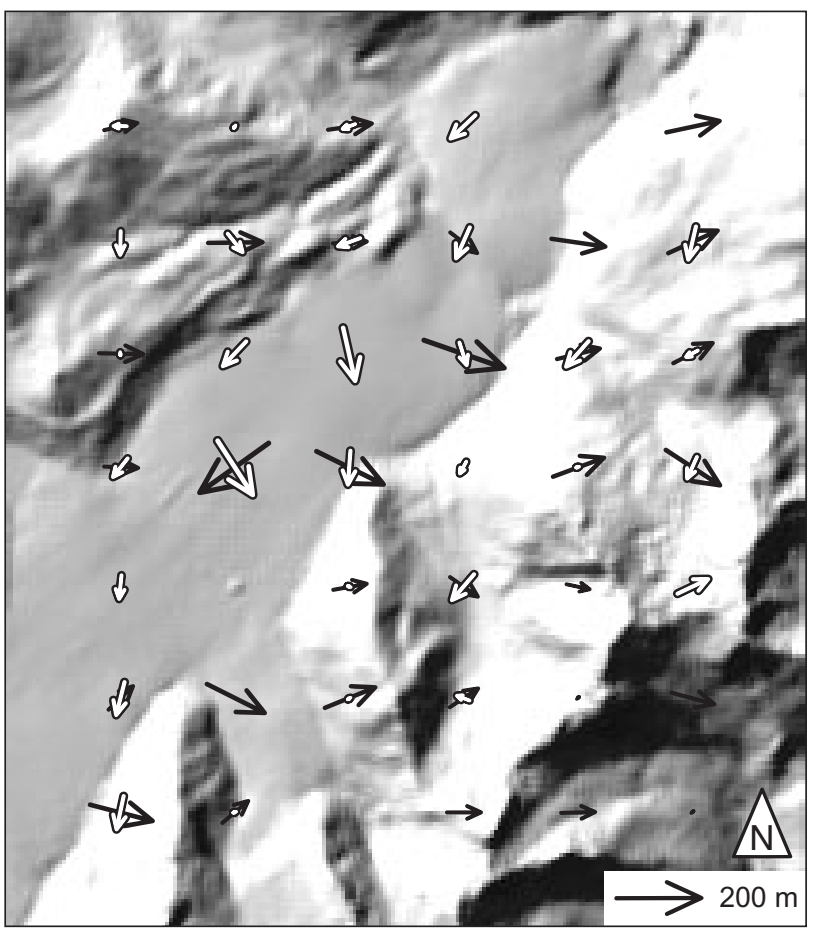

Fig. 9. Horizontal residuals from matching the SRTM DTM (white arrows) and an ASTER DTM (black arrows) onto an aerophotogrammetric reference DTM. Glaciar Chico, Southern Patagonia Icefield, Chile $\left(49.0^{\circ} \mathrm{S}, 73.1^{\circ} \mathrm{W}\right)$. Matching grid width used was $1500 \mathrm{~m}$, matching chip size was $750 \mathrm{~m}$. For the flat glacier obvious mismatches occur due to missing relief contrast. No residual vectors are available for the SRTM DTM in the lower right section due to data gaps. For the DTMs shifted according to the residual vectors the vertical deviations from the aerophotogrammetric DTM were reduced by about $10 \%$.

(RMS) of an individual elevation change $R M S_{\Delta z}$ can be estimated from the RMS of the repeat (here: two) DTMs (Etzelmüller, 2000):

$\left(R M S_{\Delta z}\right)^{2}=\left(R M S_{z 1}\right)^{2}+\left(R M S_{z 2}\right)^{2}$.

Special pre- and post-processing procedures help to reach or improve the latter accuracy:

"Pre-processing, i.e. procedures beforehand the DTM subtraction": As for all multitemporal analyses, accurate coregistration of the multiple DTMs is a necessary prerequisite to obtain elevation changes free of global systematic errors. If the repeat DTMs are produced using the same method (e.g. optical stereo), the co-registration of the DTMs (and other products) can be assured by orienting the original data as one common, multitemporal data set. For instance, repeat satellite or aerial imagery should be oriented as one (multitemporal) image block with common ground control points (GCPs) and all the images connected by (multitemporal) tie points (TPs) (Kääb and Vollmer, 2000; Kääb et al., 2004b; Kääb, 2005).

If the original sensor model and orientation is inaccessible, or the DTMs have different sources, matching between the 


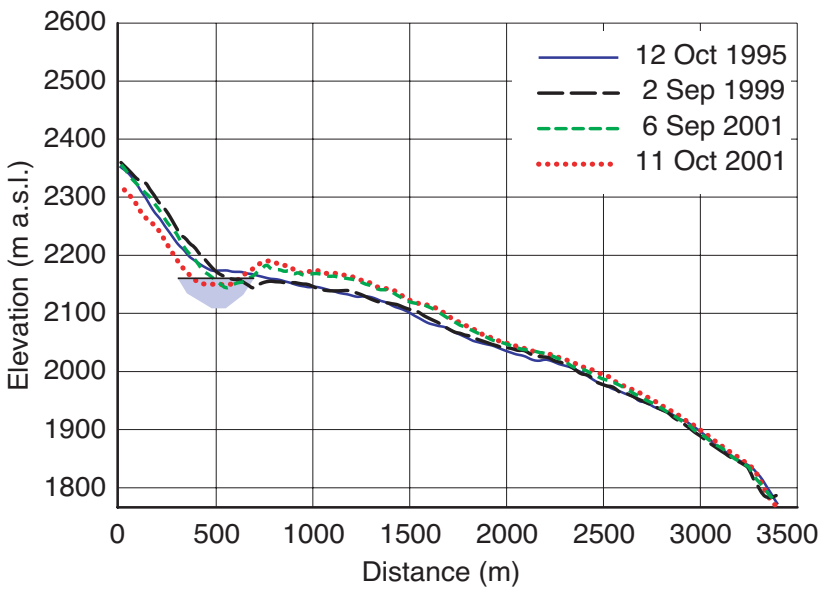

Fig. 10. Repeated longitudinal surface profiles over Ghiacciaio del Belvedere $\left(45.9^{\circ} \mathrm{N}, 7.9^{\circ} \mathrm{E}\right)$. The position of the summer 2002 supraglacial lake is indicated schematically. Since autumn 2000 the glacier experienced a surge-type movement with severe glacial hazards associated (Haeberli et al., 2002; Kääb et al., 2003c, 2004a) (see also Fig. 13).

individual DTMs to be compared is recommended. Through cross-correlation techniques the vertical and horizontal shifts of selected sections of the "slave DTM" with respect to the "master-DTM" can be measured so that the vertical differences between the DTMs to be co-registered become minimal for the stable terrain sections. From these shift vectors (Fig. 9) an optimal horizontal and vertical shift, rotation, scale, etc., between the DTMs to be compared can be computed and the "slave DTM" transformed accordingly (Pilgrim, 1996a, b; Li et al., 2001; Weidmann, 2004). The crosscorrelation focuses on stable terrain with sufficient relief (i.e. topographic contrast). Alternatively, also products of the DTMs can be matched, for instance orthoimages (Berthier et al., 2004), or DTM derivatives such as slope or curvature maps, or edge-filtered DTMs.

"Post-processing of the elevation differences": Once the raw differences between repeat DTMs are computed it is often necessary to filter the elevation differences obtained, because the noise in the derived differences is larger than in the original DTMs (see Eq. 1) (Etzelmüller, 2000; Kääb, 2004). The task is to define a noise model adapted to the nature of the process under investigation. For instance, thickness changes of a debris-free glacier are expected to show a smooth spatial variability so that a coarse filter might be applied. Coarse filters are less suited for mass movements such as landslides with a high spatial variability and with many secondary local terrain movements overlain, because the filter tends to remove important "real" signals. In general, low-pass filters exist in the spatial domain (e.g. median, medium, Gauss, etc.) or for the spectral domain (e.g. fourier or wavelet) (Kääb et al., 1997; Gudmundsson and Bauder, 1999; Etzelmüller, 2000; Kääb, 2004).

A well-established method for detecting terrain elevation changes is the subtraction of repeat aero-photogrammetric

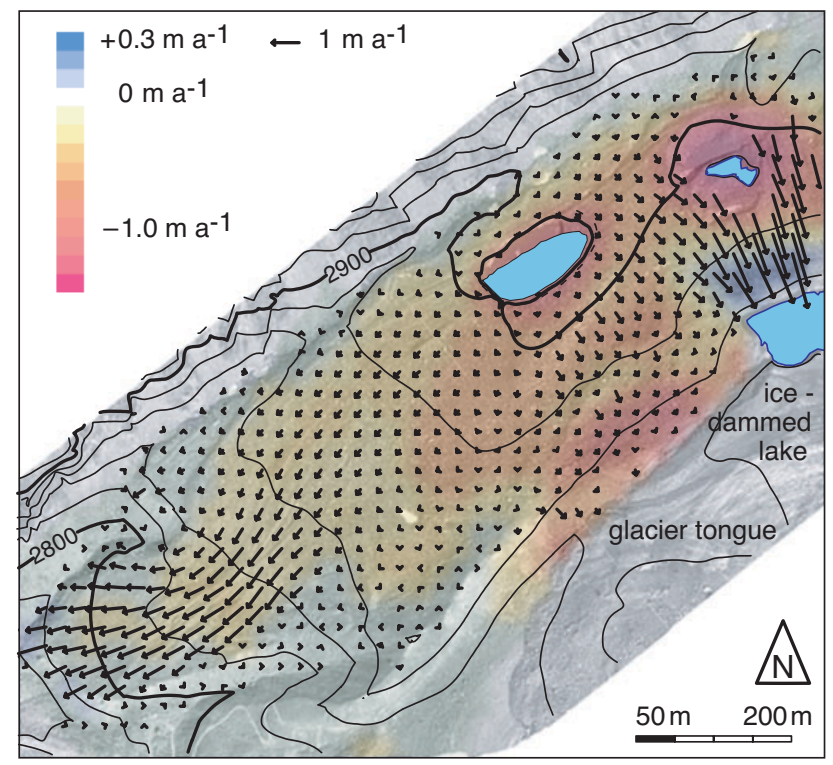

Fig. 11. Gruben rockglacier, Swiss Alps $\left(46.2^{\circ} \mathrm{N}, 7.9^{\circ} \mathrm{E}\right)$. Overlay of the horizontal surface velocities (vectors) and the colour-coded changes in elevation, both for 1970 to 1995 . The multitemporal three-dimensional data merging clearly reveals differences within the rockglacier in terms of dynamics and thermal equilibrium. To the north-east, a patchy distribution of horizontal velocities and high rates of thaw settlement indicate dead ice occurrences that are not in thermal equilibrium. To the south-west, a coherent flow field and almost constant thickness point to creeping permafrost in thermal equilibrium (Kääb et al., 1997). The lakes on Gruben rockglacier were subject to hazard assessments and mitigation measures (Haeberli et al., 2001).

DTMs. A large number of applications exists ranging from, for instance, measuring glacier thickness changes (Fig. 10) (Benson and Follet, 1986; Fox and Nuttall, 1997; Kääb and Funk, 1999; Kaufmann and Plösch, 2000; Jiskoot et al., 2001; Julio Miranda and Delgado Granados, 2003), volumes of deposited materials (Clague and Evans, 2000), permafrost agradation (i.e. development of ice lenses and connected frost heave) or degradation (e.g. melt-out of ground ice and connected thaw settlement) (Kääb et al., 1997), development of thermokarst processes or many types of peri- and paraglacial slope instabilities (Fig. 11) (Kääb, 2000, 2004; Kääb and Vollmer, 2000). Repeat laserscanning will increasingly be applied for similar studies (Geist et al., 2003).

Compared to airborne techniques, elevation changes from repeat satellite stereo can only be measured for a limited number of geomorphodynamic processes due to the reduced accuracy of the according DTMs. Nevertheless, the accuracy obtained might be sufficient to detect and quantify large changes in terrain geometry, such as from avalanche deposits or glacier mass changes (Fig. 12) (Berthier et al., 2004; Kääb, 2004).

Sometimes, also differential SAR interferometry (DInSAR) can be used to detect vertical terrain changes (e.g. Björnsson et al., 2001). However, strictly speaking this technique does track three-dimensional terrain surface shifts 
rather than elevation changes at fixed positions. The technique is therefore covered in the following section.

\section{Surface displacements}

Terrain movements can directly pose a hazard (e.g. landslides) or provoke follow-up processes, which then develop into hazards (e.g. river damming by a glacier surge). The measurement of terrain displacements from repeat image data can thus support high-mountain hazard assessments (Powers et al., 1996; Kääb et al., 1997; Knizhnikov et al., 1998; Kääb and Funk, 1999; Weber and Herrmann, 2000; Jiskoot et al., 2001; Kääb, 2002; Casson et al., 2003; Delacourt et al., 2004).

If digital image correlation techniques are used, the measurements are possible at a horizontal accuracy on the order of the pixel size of the sensor applied (Kääb, 2002). Subpixel accuracy can be reached as well but is often limited by changes in terrain and illumination conditions between the repeat data acquisitions. Image matching techniques can be applied equally to terrestrial photos, air photos, optical satellite images, SAR images (Michel and Rignot, 1999; Strozzi et al., 2002) or high-resolution DTMs (e.g. derived from laserscanning, or aerophotogrammetry). Depending on the data and technique employed either the horizontal component of the surface displacement is measured or the fully three-dimensional surface displacement vector (Kaufmann and Ladstädter, 2002; Kääb, 2004).

The rate of terrain movement, which can be detected at a statistically significant level of accuracy, depends among others on the image pixel size, the temporal baseline, and the terrain preservation between the repeated data acquisitions. From air and high-resolution satellite images slope instabilities such as rock mass movements, or permafrost creep can be detected (i.e. movement rates in the order of $\mathrm{cm}$ to $\mathrm{m}$ per year; Figs. 11, 14 and 15) (Kääb, 2002; Delacourt et al., 2004). Comparably fast movements, in particular glacier flow (i.e. rates of tens to hundreds of metres per year), can be sometimes quantified from airphotos (Fig. 13), but also from medium-resolution satellite imagery (e.g. Landsat ETM+, ASTER) (Figs. 16 and 17) (Kääb, 2002, 2005; Dowdeswell and Benham, 2003; Skvarca et al., 2003; Kääb et al., 2004b; Berthier et al., 2005).

Differential InSAR (DInSAR) enables measuring slow terrain movement with an accuracy of a few millimetres. Applicability of the method depends on terrain topography and SAR imaging geometry, leading to areas of missing information in layover and shadow, and on preservation of interferometric coherence (Ferretti et al., 2001; Nagler et al., 2002; Eldhuset et al., 2003; Strozzi et al., 2004). Coherence is usually lost when, among others, the terrain is destructed or the surface humidity changes significantly (Weydahl, 2001). In high mountains the presence of snow and its temporal changes have significant influence on the electromagnetic response in the microwave spectrum. Related interferometric de-correlation effects can be avoided by short tempo-

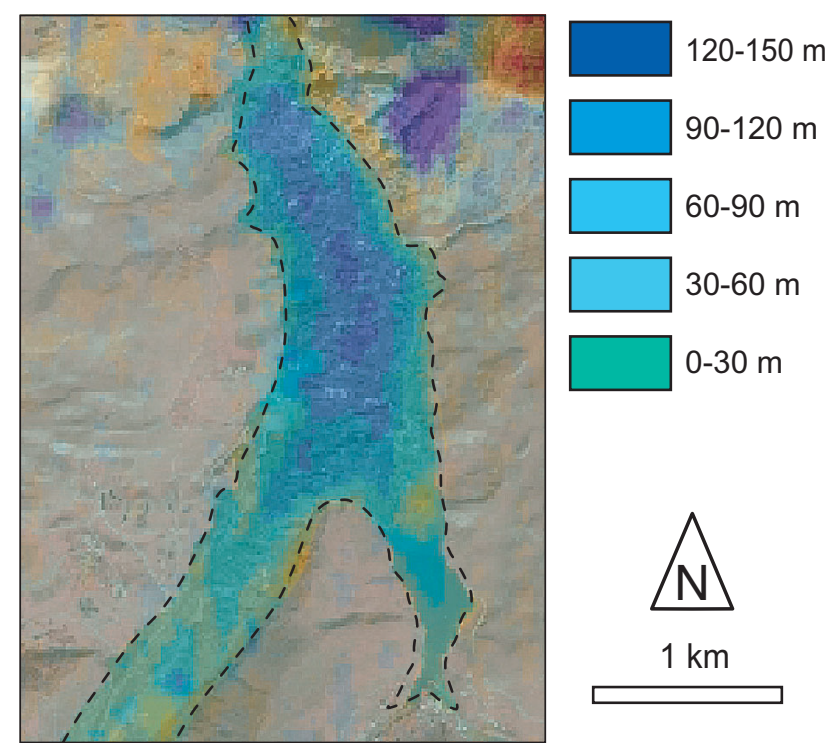

Fig. 12. Thickness of the 20 September 2002 avalanche deposits at Karmadon computed from ASTER DTMs of 22 July 2001 and 6 October 2002. The strong elevation changes to the upper right corner are due to errors in the ASTER DTMs in steep slopes (see also Figs. 4 and 5).

ral baselines, when the observed terrain movements are fast enough to be detectable over such short periods (see Fig. 18). DInSAR directly provides the line-of-sight displacement, i.e. the projection of the actual terrain displacement vector on the line between terrain point and sensor. Except for high latitudes, where ascending and descending satellite-track azimuths are significantly different, the line-of-sight displacement cannot be well decomposed into horizontal components (Joughin et al., 1999). The horizontal and vertical displacement components can be separated by combining the line-ofsight displacements measured from ascending and descending orbits, at least in theory. In mountain areas such procedure is often hindered by the fact that slopes which are well visible from the ascending orbit lie in shadow or layover in the descending orbit, and vice versa. The vertical and horizontal components have rather to be estimated or modelled from the type of terrain movement under investigation (Wang and Li, 1999; Strozzi et al., 2001). Typical DInSAR applications in high-mountains are the detection of rock mass movements, glacier flow and permafrost creep (Figs. 18 and 19) (Fruneau et al., 1996; Rignot et al., 1996; Mattar et al., 1998; Joughin et al., 1999; Rott et al., 1999; Ferretti et al., 2001; Kenyi and Kaufmann, 2001; Nagler et al., 2002; Eldhuset et al., 2003; Forster et al., 2003; Squarzoni et al., 2003; Strozzi et al., 2004).

For glacier hazard assessments, DInSAR and optical image matching methods for deriving terrain movement are highly complementary in terms of accuracy and applicability. As a very general rule, DInSAR has the potential to work where image matching fails, and vice versa (Kääb, 2004). 


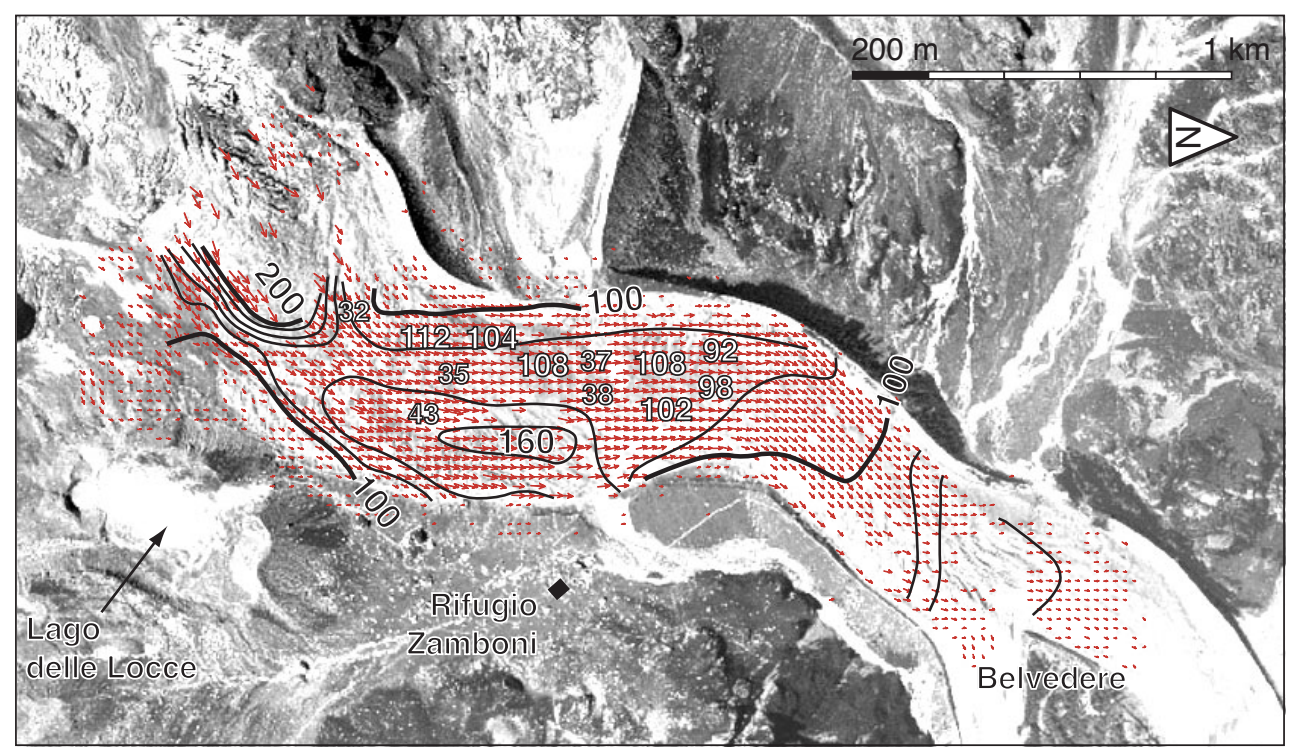

Fig. 13. Surface velocity field on Ghiacciaio del Belvedere, Italian Alps, between 6 September 2001 and 11 October 2001. Underlying orthoimage of 11 October 2001 (original air-photo () CNR-IRPI/Glaciorisk). The black numbers and isolines indicate the glacier speeds of the autumn 2001 period. The large white numbers (92-112 $\mathrm{m} \mathrm{a}^{-1}$ ) give speeds at selected points between 2 September 1999 and 6 September 2001; the smaller white numbers (32-43 $\left.\mathrm{m} \mathrm{a}^{-1}\right)$ indicate speeds from 12 October 1995 to 2 September 1999. Speeds are given in metres per year.

\section{Detection of hazard sources}

A natural hazard can be defined by (a) the kind of physical process involved, (b) the magnitude of the event, and (c) its probability or frequency. The detection of potential hazard sources and their characterisation is, therefore, an important first step in assessing glacial, peri- and paraglacial hazards. According to the complex nature of high-mountain processes, multidomain (or multidimensional) classification approaches that integrate spatial, spectral and temporal information are most promising for that task. No detailed rules for such multidomain classifications can be given due to the variety of specific requirements. In general, however, the combination of a single or repeat DTM(s) with (possibly multitemporal) multispectral data is a particularly powerful tool for detecting potential high-mountain hazard sources.

Selected examples:

- Steep glaciers, a frequent source of ice break-offs and ice avalanches, can be detected on a regional scale through the combination of a multispectral glacier classification with the DTM slope. The result is a map of steep glaciers, i.e. glaciers above a certain slope threshold (Fig. 20) (Salzmann et al., 2004).

- A texture analysis based on high-resolution satellite (or aerial) imagery combined with DTM slope helps to detect steep, and possibly frozen, debris slopes prone to debris flow initiation (Huggel et al., 2004c).

- Glacier slope, extent of debris cover, thickness changes and ice velocities can help to estimate the evolution of ice-marginal lakes or detecting glacier zones prone to the development of supraglacial lakes (Fig. 21) (Paul et al., 2004a; Kääb, 2005).

- Glacier length changes, possibly resulting in a change of ice-avalanche hazard or in proglacial lakes, can be tracked from multitemporal and -spectral classification (Paul, 2002; Paul et al., 2004a).

- Similarly, the (change in) ice cover on glacier-clad volcanoes can be detected from (repeat) multispectral imagery or aerophotogrammetry. Ice volumes situated on volcanoes can be an important factor for devastating lahars, in particular in connection with volcanic activity (Benson and Follet, 1986; Major and Newhall, 1989; Julio Miranda et al., 2005).

- Freshly deglaciated terrain sections (detectable by multi-temporal and -spectral ice classification) of rock walls (detectable through steep DTM slope, missing vegetation, and possibly texture analysis) indicate zones of potentially enhanced rockfall activity due to the thermal, mechanical, hydraulic and hydrological consequences accompanying glacier retreat (Haeberli et al., 1997).

A second class of multidomain classifications utilises not only the remotely sensed data itself, but also the outputs from process models, which might in turn be fed by remote sensing data. For instance, mountain permafrost distribution is highly dependent on elevation (as a surrogate for air temperature) and direct incoming solar radiation. The latter can be modelled based on a DTM (Hoelzle, 1996). A permafrost 
distribution map is then a valuable requisite for detecting possible slope instabilities connected to permafrost or permafrost thaw in debris or rock slopes (Zimmermann et al., 1997; Noetzli et al., 2003). As a second example, potentially debris-producing rock walls can be approximated as steep DTM sections without vegetation. Rockfall modelled from such terrain sections can then support remote sensing-based detection of debris slopes (Zemp et al., 2005).

\section{Modelling of hazard potentials}

Once potential hazard sources have been detected, mass movement models help estimating potentially affected zones. The most important prerequisite of such models is a DTM, best obtained through remote sensing. This relates to the importance of topography for controlling mass-movement downslope propagation. Further, remote sensing supports mass movement modelling by providing model inputs through image classification such as surface cover, surface roughness, material to be potentially mobilised, etc. Types of mass movement models applied to glacial, peri- and paraglacial hazards are (Huggel, 2004):

- "empirical rules and models", where important parameters such as maximum discharge of lake outbursts, starting slope and volume of ice avalanches, or maximum travel distances for glacier floods, debris flows, or ice and rock avalanches are statistically estimated from according events (e.g. Huggel et al., 2004a). Some of these parameters can be derived through remote sensing data from before and/or after an event (e.g. Figs. 4 and 12).

- "numerical models", where the governing physics of a mass movement type are typically represented by differential equations, which are then solved through numerical methods such as numerical integration, finite differences or finite elements. Other models of the numerical type simulate, for instance, the forces and related movement of point masses (e.g. Bottino et al., 2002). Remotely sensed data are often used to define the boundary conditions of numerical models (e.g. terrain geometry, velocities; Figs. 10-19).

- "probabilistic models", which result in the probability of a certain action, for instance related to geomorphometric parameters such as slope, slope length, etc. (Mostyn and Li, 1993; Harbitz et al., 2001). Alternatively, a mass movement is modelled by many repeat runs with changing starting, transition and deposition conditions (so-called Monte Carlo models) (Gamma, 2000; Barbolini and Savi, 2001). The resulting pattern of how often a terrain cell is hit by the mass movement reflects then some kind of probability. A similar class of models aims to estimate the possibility of an event, for instance through fuzzy logic. Typically, remote sensingderived DTMs form the base for probabilistic models.

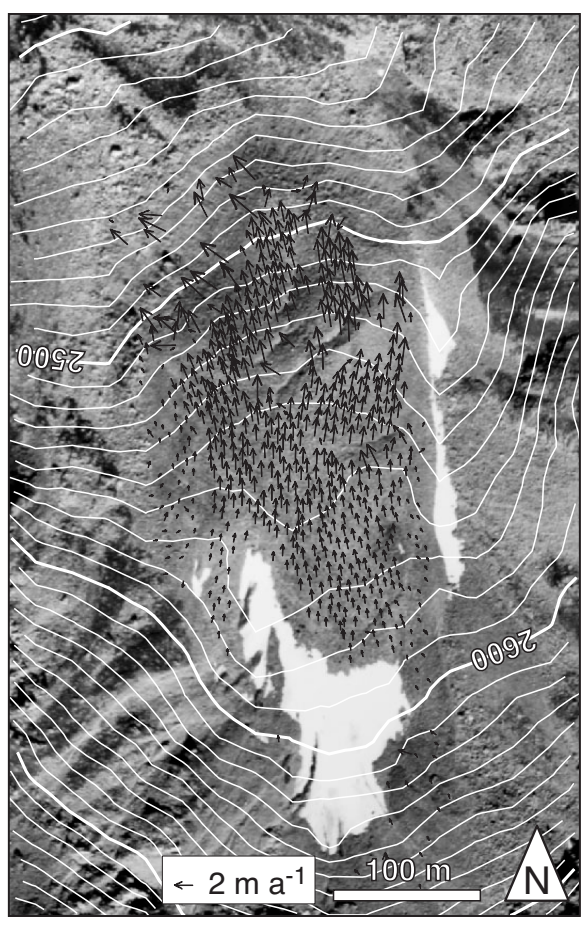

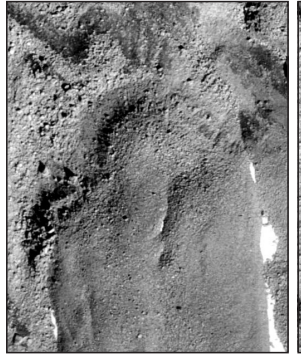

1975

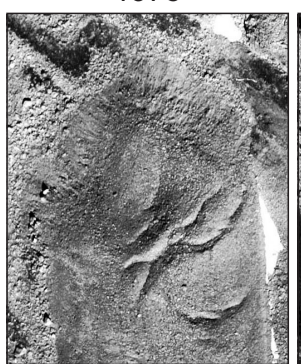

1993

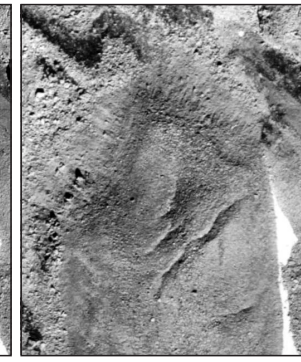

1987

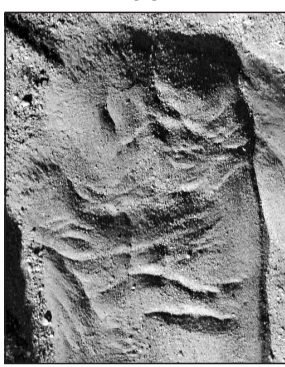

2001
Fig. 14. Instability of a rockglacier terminus, Turtmanntal, Swiss Alps $\left(46.2^{\circ} \mathrm{N}, 7.7^{\circ} \mathrm{E}\right)$. Upper panel: velocity vectors measured from airphotos of 1987 and 1993; lower panels: orthophotos of the terminus section of the rockglacier. Images of 1975, 1987, and 1993 are courtesy of swisstopo; the 2001 image is a linear array CCD (pushbroom) image taken by the HRSC-A camera, courtesy of Department of Geography, University of Bonn. The rockglacier instability led to enhanced rockfall and required construction of a protection dam (not depicted) (see also Roer et al., 2005).

- "hydrological flow-routing models", where the mass movement is for the most part purely gravity-driven. Different approaches exist how the (maximum) slope is determined, which decides about the flow direction 


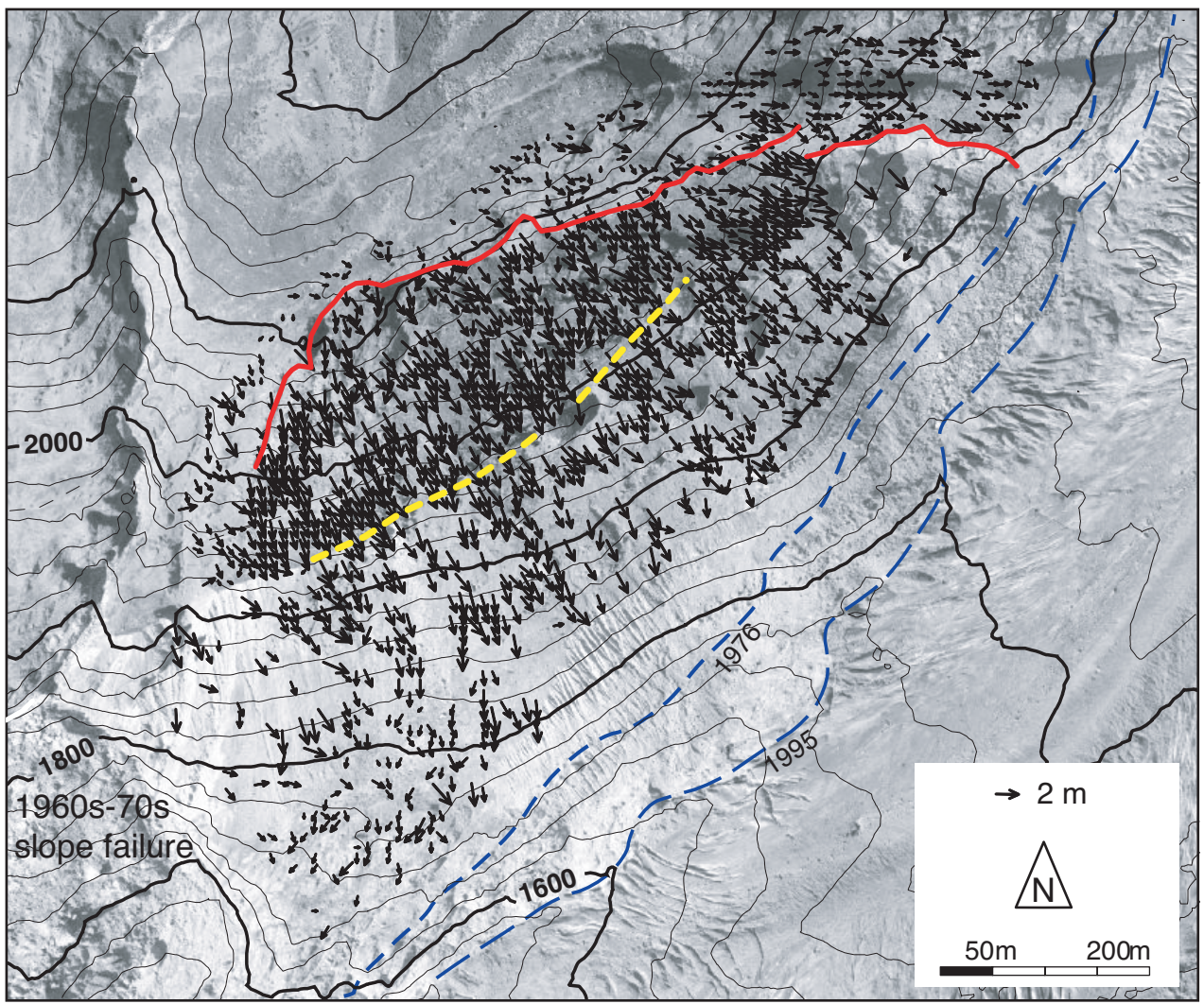

Fig. 15. Displacements on a rock mass creep near the tongue of Aletsch Glacier, Swiss Alps $\left(46.4^{\circ} \mathrm{N}, 8.0^{\circ} \mathrm{E}\right)$, derived on the basis of orthoimages from 1976 and 1995. For location see also Fig. 19. In the lower left corner the deposits from a rock slope failure from the late 1960s to early 1970s are located. The solid red line to the north marks the upper scarp of the slide; the dashed yellow line in the centre marks the Little Ice Age (LIA) glacier moraine (about 1850). To the south-east, the glacier boundaries of 1976 and 1995 are marked by blue dashed lines. The underlying orthoimage from 1995 is based on aerial photography by the swisstopo flight service. Maximum terrain deformation amounts to $2 \mathrm{~m}$. The retreat of Great Aletsch Glacier from its LIA extent and the accompanying loss of ice thickness (up to $300 \mathrm{~m}$ ) caused a stress redistribution in the valley flank and related destabilisation (Kääb, 2002).

from one terrain cell to the next (Figs. 22 and 23) (Meissl, 1998; Liang and MacKay, 2000; Dorren, 2003; Dorren and Seijmonsbergen, 2003; Stevens et al., 2003; Huggel et al., 2004c; Salzmann et al., 2004; Sheridan et al., 2004; Noetzli et al., 2005). Hydrological flowrouting models can be modified in order to give some probability measures (Huggel et al., 2003b) or to allow estimates of the mass volumes involved (Iverson et al., 1998). This class of models requires suitable DTMs, which are remote sensing-derived in most cases.

- "physical or laboratory models", where the terrain and a mass movement process are scaled down to small size and simulated physically in the laboratory. For instance debris flows, or creep of frozen or viscous masses (Kääb and Weber, 2004). To such models close-range remote sensing techniques such as particle tracking, or laser and microwave sounders can be applied.

Most outputs of these models are highly sensitive to DTM characteristics such as resolution, level of detail, or vertical and horizontal errors. A sound understanding and evaluation of the remotely sensed DTM used for a simulation is therefore important. Related sensitivity studies can result in multiple model outputs based on different input DTMs and/or different models (Figs. 22 and 23) (Huggel et al., 2003b; Salzmann et al., 2004).

Geographic information systems (GIS) have become a standard tool for the integration of base data (e.g. digital maps and orthoimages), model input data (e.g. DTMs and terrain classification), model outputs (e.g. affected areas), and - for a number of models - also the model itself.

Depending on the input parameters and/or empirical relations used, models can provide different hazard scenarios (e.g. different distances of reach, relative or absolute probabilities) and hazard maps can be derived. Once a model indicates potentially endangered areas, remote sensing supports the mapping and investigation of settlements and infrastructure at risk, or the assessment of possible chain reactions and secondary effects (e.g. Huggel et al., 2004c).

Spaceborne, airborne and terrestrial methods for glacier and permafrost hazard assessment can be integrated within a down-scaling strategy ranging from first-order assessments 


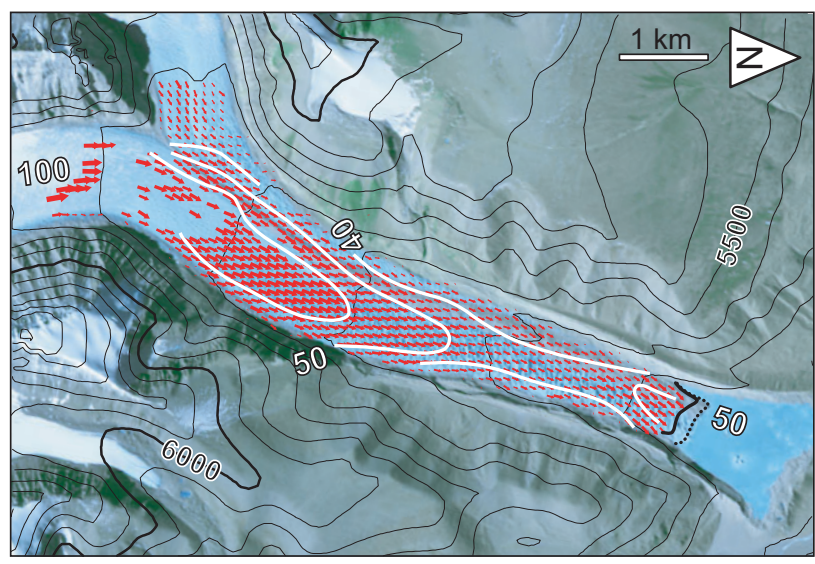

Fig. 16. Horizontal surface velocities on a glacier (name unpublished) at the northern slope of the Bhutan Himalaya towards the Tibet plateau $\left(28.2^{\circ} \mathrm{N}, 90.0^{\circ} \mathrm{E}\right)$, derived from ASTER data of 20 January 2001 and 20 November 2001. Speed isolines are in $\mathrm{m}$ per year. Contour lines are in $\mathrm{m}$ a.s.l. and derived from the SRTM DTM. The dotted line at the calving front marks its position in $01 / 2001$; the bold line is the $11 / 2001$ position. Ice flux is an important factor influencing the development of proglacial ice-contact lakes.

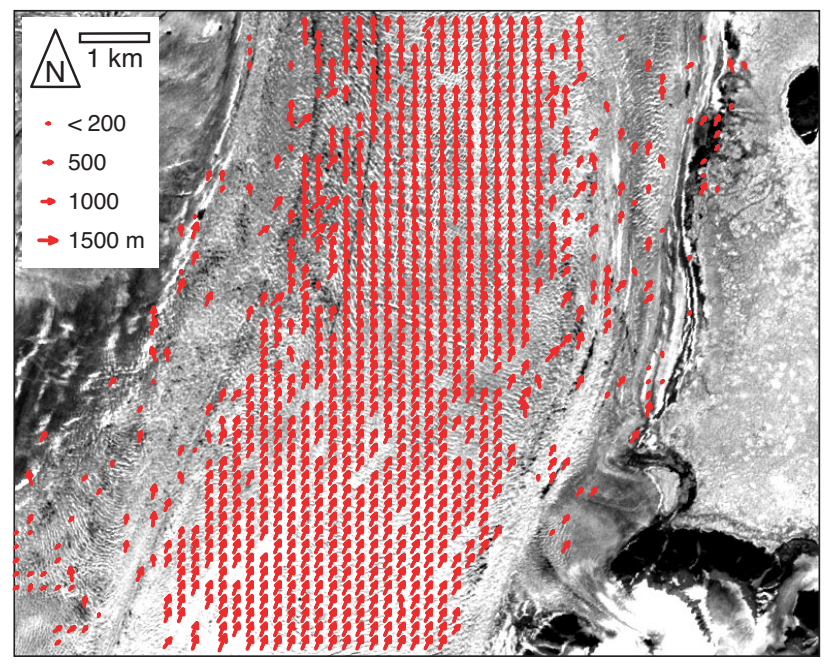

Fig. 17. Velocity field for a section of Mittie glacier, Manson ice cap, Ellesmere Island, Canadian High Arctic $\left(76.7^{\circ} \mathrm{N}, 79.2^{\circ} \mathrm{W}\right)$, computed from Landsat ETM+ pan orthoimagery of 13 July 1999 and 27 June 2000. Displacements amount up to $1500 \mathrm{~m}$. Original measurements were performed with $100 \mathrm{~m}$ spacing, but are depicted with $200 \mathrm{~m}$ spacing for better readability. Mittie glacier was surging during the observation period (Copland et al., 2003). The Landsat imagery was processed and provided by Luke Copland, Department of Earth and Atmospheric Sciences, University of Alberta, Edmonton.

with regional coverage towards detailed local investigations. Even when dealing with local problems such as known hazard sources or disaster management, regional-scale firstorder assessments should be part of hazard assessments in high mountains in order to account for hazard combinations,
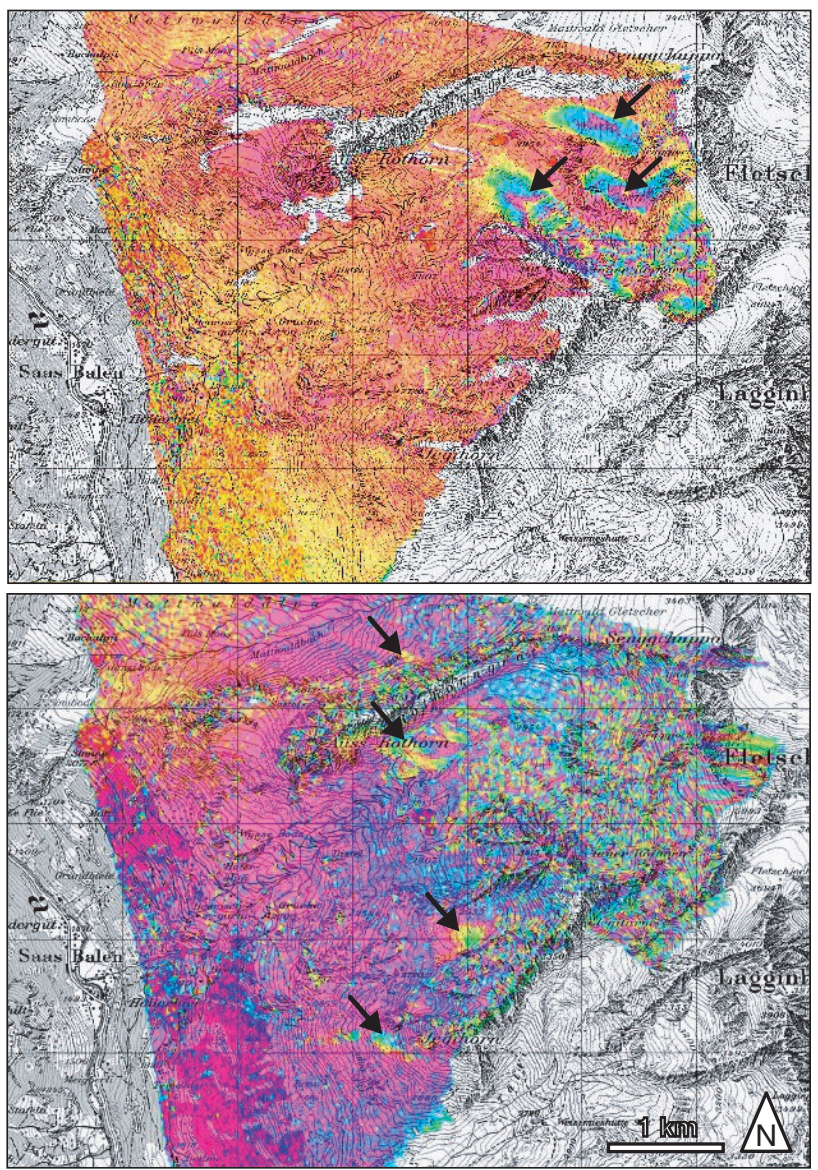

Fig. 18. Differential Interferometric Synthetic Aperture Radar (DInSAR) interferograms over the Gruben area, Swiss Alps (see Fig. 11). Upper panel: glacier flow (arrows) as detected from an ERS 1/2 pair of 7-8 March 1996 (maximum speed on the order of $10-20 \mathrm{~cm} \mathrm{~d}^{-1}$ ). Lower panel: rockglacier creep (arrows) as detected from a JERS pair of 21 June 1996-17 September 1996 (maximum speed on the order of $50 \mathrm{~cm} \mathrm{a}^{-1}$ ) (Strozzi et al., 2003a; Strozzi et al., 2004). One colour cycle indicates a displacement of about $2.8 \mathrm{~cm}$ for ERS, or $11.5 \mathrm{~cm}$ for JERS, in the line-of-sight direction, i.e. in approximately east-west direction. Background map by permision of Swisstopo BA024706. For the interferogram with a 1-day temporal baseline (upper panel) the comparable fast glacier flow can well be detected, whereas the slow permafrost creep gives no movement signal. On the other hand, the permafrost creep can well be detected in the interferogram with an 88-day temporal baseline, where interferometric phase de-correlation prevails on the glaciers due to snow- and ice-melt and due to too large displacements.

chain reactions, and secondary hazards. In particular satellite remote sensing is the method of choice for such work.

\section{Disaster management}

Above section relates to hazards, i.e. potential processes, the following section to actions after a catastrophic event. Integrating remote sensing in the management of glacier- and permafrost-related disasters can serve three major applied 

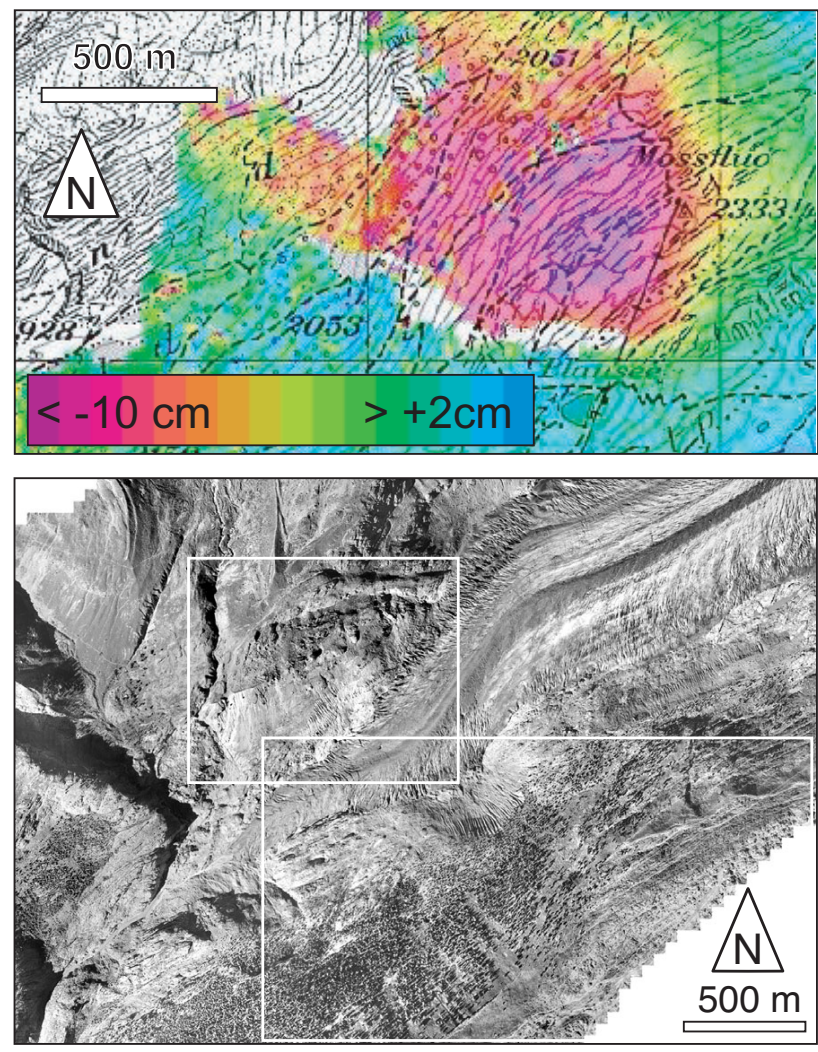

Fig. 19. Aletschwald, Swiss Alps $\left(46.4^{\circ} \mathrm{N}, 8.0^{\circ} \mathrm{E}\right)$. Upper panel: displacement magnitude map for a time interval of 1144 days (17 June 1993-4 August 1996) derived from repeat JERS SAR data. Displacement direction is assumed to be down-slope to the northwest. As yet the site has not been investigated in detail. However, a number of comparable movements situated nearby and studied already (see lower panel) hint to rock-slope creeping to be the cause for the displacements observed. Lower panel: Tongue of Aletsch Glacier with white rectangles indicating the location of this DInSAR study (lower rectangle) and the photogrammetric study Fig. 15 (upper rectangle).

and scientific needs: (i) overview of disaster and damage extent, (ii) frequent monitoring, and (iii) documentation. (i) and (ii) are directed towards search and rescue operations and civil protection, and primarily require a rapid and repeat data acquisition and processing (e.g. Kääb et al., 2003c). Due to the limitations of optical remote sensing during cloud cover and night time, the application of (repeat) weatherand sun-independent SAR data can be especially important (Kerle and Oppenheimer, 2002). The major problems related to (i) and (ii) are the enduser-capacity to handle and analyse the data, and the speed of data acquisition and delivery. Remotely sensed documentation of a disaster (iii), even if the data are not analysed immediately, can be an unique source for thoroughly investigating the processes involved, and drawing scientific and applied conclusions of broader interest (Huggel et al., 2005).

The International Charter "Space and Major Disasters" offers potentially important remote-sensing support for man-

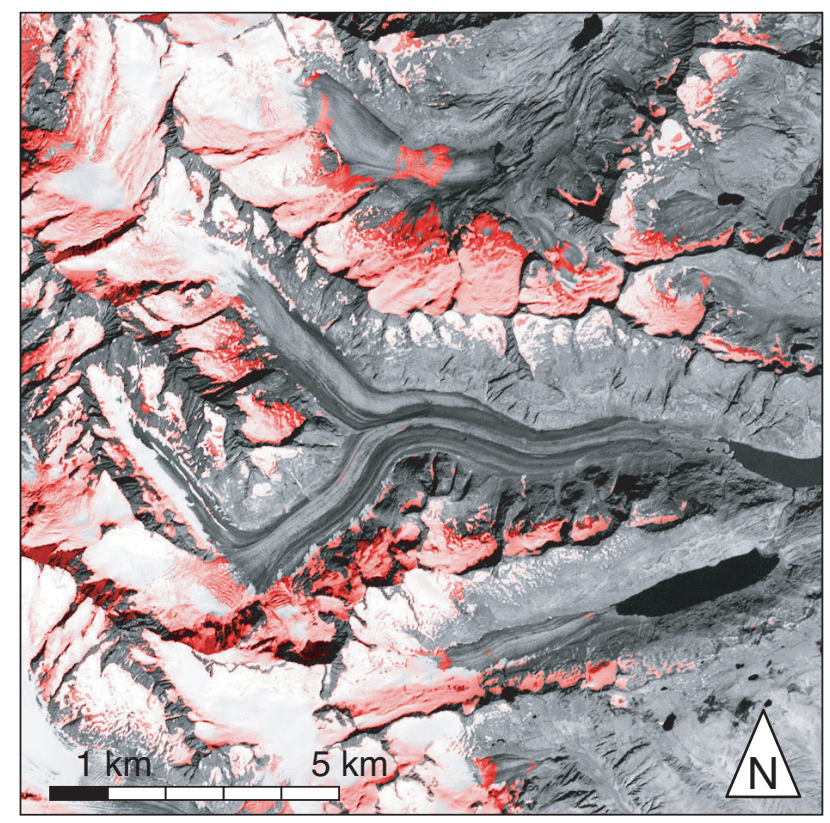

Fig. 20. Steep glaciers as determined by a combination of a thresholded ASTER band 3/ASTER band 4 ratio-image and a thresholded slope map with slope greater than $30^{\circ}$ (Unteraar Glacier, Swiss Alps, $46.6^{\circ} \mathrm{N}, 8.2^{\circ} \mathrm{E}$ ). The image resulting from this procedure was coloured red and the intensity component taken from ASTER band 3. As a result glaciers steeper than $30^{\circ}$ appear red in the figure. Detection of steep glaciers is e.g. a prerequisite for the modelling of ice-avalanche hazard potentials. According to empirical investigations in the Swiss Alps cold glaciers produce ice avalanches from a minimum bed slope of $45^{\circ}$, temperate glaciers from $25^{\circ}$ (Alean, 1985; Salzmann et al., 2004).

aging large glacier and permafrost disasters. Within this contract, a number of space agencies and commercial satellite companies provide under certain circumstances rapid and free emergency imaging. Currently involved sensors include ENVISAT, ERS, IRS, Radarsat, or SPOT. Only selected national and international civil protection, rescue and security authorities can activate the Charter (www.disasterscharter.org). Also, the ASTER sensor onboard the Terra spacecraft can be activated for supporting disaster management (Kääb et al., 2003c).

\section{Conclusions and perspectives}

Remote sensing will increasingly become an important and integrative component of managing glacier and permafrost hazards. In this contribution we give an overview of air- and spaceborne techniques available to support the assessment of glacier and permafrost hazards. We evaluate their potential and limitations by means of various case studies.

The best-established and most robust remote-sensing method for detailed investigations considered in this work is aerophotogrammetry, which enables image interpretation, DTM generation, and displacement measurement with 


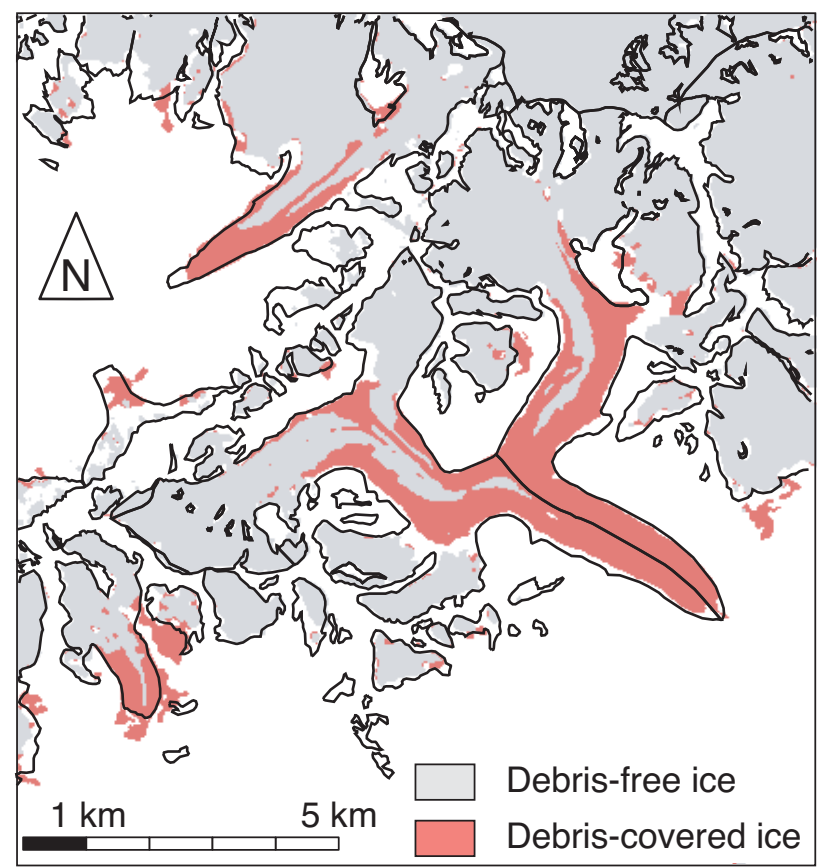

Fig. 21. Automatic mapping of debris-covered ice from merging spectral data and DTM-slope $\left(46.4^{\circ} \mathrm{N}, 7.9^{\circ} \mathrm{E}\right)$. Areas that (1) have a slope $<23^{\circ}$, (2) are not vegetated according to the normalized difference vegetation index (NDVI), and (3) are in direct contact with debris-free ice as mapped from a thresholded ratio-image (Landsat TM band 4/Landsat TM band 5) are classified as debris-covered ice (Paul, 2004). The black glacier outlines are taken from the 1973 Swiss glacier inventory (Maisch et al., 1999). Often, the distribution of supraglacial lakes is connected to flat, debris-covered glacier tongues.

centimetre- to metre-accuracy. For regional scale investigations and/or areas that are inaccessible on ground and by airborne platforms, spaceborne optical remote sensing is the tool, which works most robust and is most easily applied. This method enables (semi-)automatic classifications, measurement of strong and large-scale displacements, and for certain instruments also DTM generation - all with an accuracy on the order of metres to tens of metres. Air- and spaceborne photogrammetry are presently converging through the advent of high-resolution space sensors.

SAR data have a large potential to overcome some limitations of optical data, or to complement results from optical data (e.g. DTM generation, displacement measurement with millimetre-accuracy). Thus, the SRTM DTM indeed significantly facilitates hazard assessments in remote highmountain areas. However, the dissemination of expertise about SAR technology has to be improved, and the analysis methods have to become more robust and cheaper in order to facilitate the widespread application of the technique to glacier and permafrost hazard in mountains. Further research is in particular needed to better understand the complex microwave backscatter and to retrieve information about the surface and its changes from this backscatter.

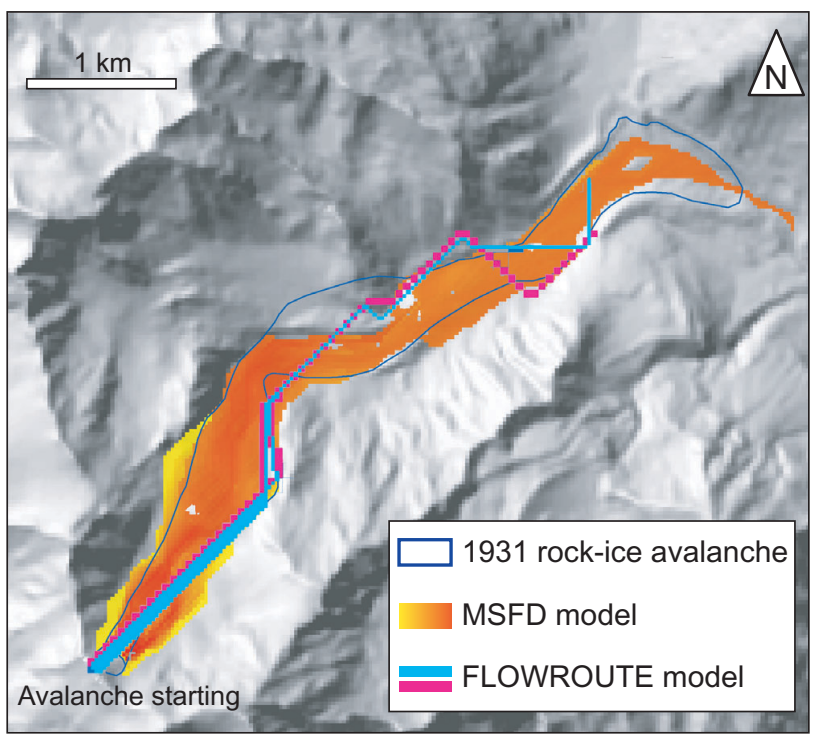

Fig. 22. Models of the 1931 rock-ice avalanche from Fletschhorn, Simplon, Swiss Alps $\left(46.2^{\circ} \mathrm{N}, 8.0^{\circ} \mathrm{E}\right)$. Blue outline: actual avalanche path; yellow to red zone: modified single flow direction model (Huggel et al., 2003b; Noetzli, 2003; Noetzli et al., 2005); blue zones: mass movement model based on energy conservation and impulse; pink zones: as blue zones, but resampled DTM (Schlaefli, 2005).

Air- and spaceborne remote sensing offers support for assessing the hazard disposition (i.e. the hazard potential), rather than enabling the observation of trigger conditions and the direct short-term forecast of events. In rare occasions, an exception of this general rule might be high-frequency imaging (e.g. monitoring of meteorological events, Kniveton et al., 2000; Buchroithner, 2002). However, the early warning from impending disasters is an ultimate, long-term goal of earth observation from space and air, and of the related technological development. For the estimation of event magnitude and frequency remote sensing data have typically to be combined with models and/or empirical data.

A major factor currently limiting the accuracy and applicability of spaceborne sensors for glacier and permafrost hazards is their spatial resolution. Data from high-resolution sensors such as IKONOS, QuickBird or Orbview3 open new possibilities in this respect, but are still very expensive and only able to cover small areas. An increasing number of satellites with SAR instruments onboard such as ERS-2, Radarsat-1, ENVISAT or the planned TerraSAR-X, ALOS and Radarsat-2, will make SAR a progressively interesting tool for glacier and permafrost hazard assessments.

Spaceborne methods are clearly preferable, or even the only possibility, to obtain base data for regional-scale glacier and permafrost hazard assessments in mountains. Their limitations with respect to spatial resolution and accuracy make these methods rather applicable for the detection of hazard potentials, or for the level of hazard indication maps (scales 1:25000-1:50 000). For more detailed hazard assessments, 

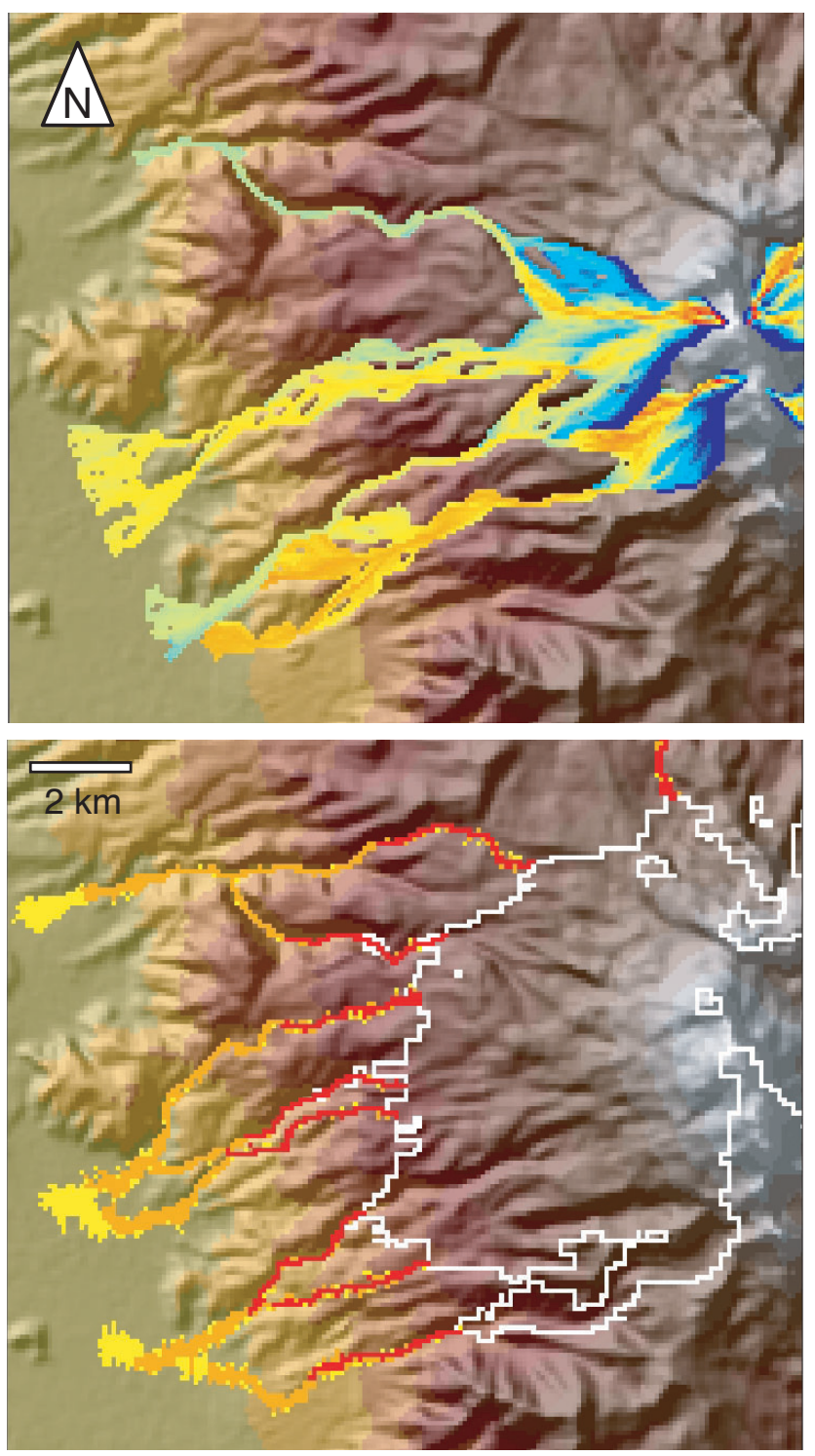

Fig. 23. Simulated lahars from the west flank of the ice-clad Iztaccihuatl volcano, Mexico $\left(19.2^{\circ} \mathrm{N}, 98.7^{\circ} \mathrm{W}\right)$. Background hillshade with colour-coded elevations and topographic base of both model runs is from the SRTM3 DTM. Upper panel: the modified single flow model MSF (Huggel et al., 2003b) initiated at the volcano top and stopped at $19 \%$ overall slope. Lower panel: the LAHARZ model (Iverson et al., 1998) with volumes of $100000 \mathrm{~m}^{3}$ (red), $500000 \mathrm{~m}^{3}$ (orange), and $1000000 \mathrm{~m}^{3}$ (yellow) starting at the so-called high-energy cone of the volcano (white outline).

above-presented airborne methods, high-resolution spaceborne methods, or terrestrial surveys are necessary.

Modern space technologies enable initial estimation of hazard potentials to be performed by virtually everyone and everywhere, independent of political and geographical restrictions. This fundamental "democratisation" process related to high-mountain (and other) hazards involves a number of new opportunities, dangers and responsibilities for the public, the authorities in charge, and the experts involved. Hazard assessment based on spaceborne remote sensing has, therefore, to follow certain rules considering these responsibilities and the consequences of their disregard. According recommendations are presently compiled by the international working group on glacier and permafrost hazards in mountains by the Commission on Cryospheric Sciences (CCS) and the International Permafrost Association (IPA).

Acknowledgements. Special thanks are due to M. Chiarle and an anonymous referee for their helpful comments. The ASTER scenes used in the presented studies were provided within the framework of the Global Land Ice Measurements from Space project (GLIMS) through the EROS data center, and are courtesy of NASA/GSFC/METI/ERSDAC/JAROS, and the US/Japan ASTER science team. The airphotos used for the Gruben and Aletsch studies are courtesy of the swisstopo flight service. ERS SAR data courtesy AO3-178, (C ESA; JERS SAR data courtesy J-2RI-001, ( NASDA; processing GAMMA, Berne. Some of the studies were conducted for, or in close co-operation with the Swiss Agency for Development and Cooperation (SDC), the Macugnaga studies in co-operation with the regional and national civil protection authorities.

Edited by: F. Guzzetti

Reviewed by: M. Chiarle and another referee

\section{References}

Ageta, Y., Iwata, S., Yabuki, H., Naito, N., Sakai, A., Narama, C., and Karma: Expansion of glacier lakes in recent decades in the Bhutan Himalayas, in: Debris-Covered Glaciers, edited by: Nakawo, M., Raymond, C. F., and Fountain, A., IAHS Publication, 264, 165-175, 2000.

Al-Rousan, N. and Petrie, G.: System calibration, geometric accuracy testing and validation of DEM \& orthoimage data extracted from SPOT stereopairs using commercially available image processing systems, International Archives of Photogrammetry \& Remote Sensing, 34, 4, 8-15, 1998.

Albert, T.: Evaluation of remote sensing techniques for ice-area classification applied to the tropical Quelccaya ice cap, Peru, Polar Geography, 26, 3, 210-226, 2002.

Alean, J.: Ice avalanche activity and mass balance of high-altitude hanging glaciers in the Swiss Alps, Annals of Glaciology, 6, 248-249, 1985.

Aniya, M., Sato, H., Naruse, R., Skvarca, P., and Casassa, G.: The use of satellite and airborne imagery to inventory outlet glaciers of the Southern Patagonia Icefield, South America, Photogrammetric Engineering and Remote Sensing, 62, 1361-1369, 1996.

Baltsavias, E. P., Favey, E., Bauder, A., Boesch, H., and Pateraki, M.: Digital surface modelling by airborne laser scanning and digital photogrammetry for glacier monitoring, Photogrammetric Record, 17, 98, 243-273, 2001.

Baltsavias, E. P., Li, H., Mason, S., Stefanidis, A., and Sinning, M.: Comparison of two digital photogrammetric systems with emphasis on DTM generation: case study glacier measurement, International Archives of Photogrammetry and Remote Sensing, 31, 4, 104-109, 1996.

Barbolini, M. and Savi, F.: Estimate of uncertainties in avalanche hazard mapping, Annals of Glaciology, 32, 299-305, 2001.

Bauer, A., Paar, G., and Kaufmann, V.: Terrestrial laser scanning for rock glacier monitoring. Proceedings, Eighth International Conference on Permafrost, Zurich, Balkema, 1, 55-60, 2003. 
Benson, C. S. and Follet, A. B.: Application of photogrammetry to the study of volcano-glacier interactions on Mount Wrangell, Alaska, Photogrammetric Engineering and Remote Sensing, 52, 6, 813-827, 1986.

Berthier, E., Arnaud, Y., Baratoux, D., Vincent, C., and Remy, F.: Recent rapid thinning of the "Mer de Glace" glacier derived from satellite optical images, Geophys. Res. Lett., 31, L17401, doi:10.1029/2004GL020706, 2004.

Berthier, E., Vadon, H., Baratoux, D., Arnaud, Y., Vincent, C., Feigl, K. L., Remy, F., and Legresy, B.: Surface motion of mountain glaciers derived from satellite optical imagery, Rem. Sen. Env., 95, 14-28, 2005.

Bindschadler, R. and Vornberger, P.: Detecting ice-sheet topography with AVHRR, RESURS-01, and Landsat TM imagery, Photogrammetric Engineering and Remote Sensing, 66, 4, 417-422, 2000.

Bishop, M. P., Kargel, J. S., Kieffer, H. H., MacKinnon, D. J., Raup, B. H., and Shroder, J. F.: Remote-sensing science and technology for studying glacier processes in high Asia, Annals of Glaciology, 31, 164-170, 2000.

Björnsson, H., Rott, H., Gudmundsson, S., Fischer, A., Siegel, A., and Gudmundsson, M. T.: Glacier-volcano interactions deduced by SAR interferometry, J. Glaciol., 47, 156, 58-70, 2001.

Bottino, G., Chiarle, M., Joly, A., and Mortara, G.: Modelling rock avalanches and their relation to permafrost degradation in glacial environments, Permafrost and Periglacial Processes, 13, 4, 283 288, 2002

Brecher, H. and Thompson, L. G.: Measurement of the retreat of Qori Kalis in the tropical Andes of Peru by terrestrial photogrammetry, Photogrammetric Engineering and Remote Sensing, 59, 1017-1022, 1993.

Buchroithner, M. F.: Meteorological and earth observation remote sensing data for mass movement preparedness, Adv. Space Res., 29, 1, 5-16, 2002.

Buchroithner, M. F., Jentsch, G., and Waniverhaus, B.: Monitoring of recent glaciological events in the Khumbu Area (Himalaya, Nepal) by digital processing of Landsat MSS data, Rock Mechanics, 15, 4, 181-197, 1982.

Casson, B., Delacourt, C., Baratoux, D., and Allemand, P.: Seventeen years of the "La Clapière" landslide evolution analysed from ortho-rectified aerial photographs, Engineering Geology, 68, 12, 123-139, 2003.

Chandler, J.: Effective application of automated digital photogrammetry for geomorphological research, Earth Surface Processes and Landforms, 24, 1, 51-63, 1999.

Clague, J. J. and Evans, S. C.: A review of catastrophic drainage of moraine-dammed lakes in British Columbia, Quaternary Science Reviews, 19, 17-18, 1763-1783, 2000.

Coltelli, M., Fornaro, G., Franceschetti, G., Lanari, R., Migliaccio, M., Moreira, J. R., Papathanassiou, K. P., Puglisi, G., Riccio, D., and Schwäbisch, M.: SIR-C/X-SAR multifrequency multipass interferometry: A new tool for geological interpretation, J. Geophys. Res., 101, 23 127-23 148, 1996.

Copland, L., Sharp, M. J., and Dowdeswell, J.A.: The distribution and flow characteristics of surge-type glaciers in the Canadian High Arctic, Annals of Glaciology, 36, 73-81, 2003.

Crosetto, M.: Calibration and validation of SAR interferometry for DEM generation, ISPRS Journal of Photogrammetry and Remote Sensing, 57, 3, 213-227, 2002.

Cuartero, A., Felicisimo, A. M., and Ariza, F.J.: Accuracy, reliability, and depuration of SPOT HRV and Terra ASTER digital elevation models, IEEE Transactions on Geoscience and Remote
Sensing, 43, 2, 404-407, 2005.

Dean, K. G., Dehn, J., Papp, K. R., Smith, S., Izbekov, P., Peterson, R., Kearney, C., and Steffke, A.: Integrated satellite observations of the 2001 eruption of Mt. Cleveland, Alaska, Journal of Volcanology and Geothermal Research, 135, 1-2, 51-73, 2004.

Delacourt, C., Allemand, P., Casson, B., and Vadon, H.: Velocity field of "La Clapière" landslide measured by the correlation of aerial and QuickBird satellite images, Geophys. Res. Lett., 31, 15, L15619, doi:10.1029/2004GL020193, 2004.

Dorren, L. K. A.: A review of rockfall mechanics and modelling approaches, Progress in Physical Geography, 27, 1, 69-87, 2003.

Dorren, L. K. A. and Seijmonsbergen, A. C.: GIS-based rockfall modelling at regional scale, Geomorphology, 56, 1-2, 49-64, 2003.

Dowdeswell, J. A. and Benham, T. J.: A surge of Perseibreen, Svalbard, examined using aerial photography and ASTER highresolution satellite imagery, Polar Research, 22, 2, 373-383, 2003.

Eckert, S., Kellenberger, T., and Itten, K.: Accuracy assessment of automatically derived digital elevation models from ASTER data in mountainous terrain, International Journal of Remote Sensing, 26, 9, 1943-1957, 2005.

Ehlers, M. and Welch, R.: Stereocorrelation of Landsat TM images, Photogrammetric Engineering and Remote Sensing, 53, 12311237, 1987.

Eldhuset, K., Andersen, P. H., Hauge, S., Isaksson, E., and Weydahl, D. J.: ERS tandem INSAR processing for DEM generation, glacier motion estimation and coherence analysis on Svalbard, International Journal of Remote Sensing, 24, 7, 1415-1437, 2003.

Engeset, R. V. and Weydahl, D. J.: Analysis of glaciers and geomorphology on Svalbard using multitemporal ERS-1 SAR images. IEEE Transactions on Geosciences and Remote Sensing, 36, 6, 1879-1887, 1998.

Espizua, L. E. and Bengochea, J. D.: Surge of Grande del Nevado Glacier (Mendoza, Argentina) in 1984: its evolution through satellite images, Geografiska Annaler, 72A, 3-4, 255-259, 1990.

Etzelmüller, B.: On the quantification of surface changes using gridbased digital elevation models (DEMs), Transactions in GIS, 4, 2, 129-143, 2000 .

Evans, S. G. and Clague, J. J.: Recent climatic change and catastrophic geomorphic processes in mountain environments, Geomorphology, 10, 107-128, 1994.

Favey, E., Geiger, A., Gudmundsson, G. H., and Wehr, A.: Evaluating the potential of an airborne laser scanning system for measuring volume changes of glaciers, Geografiska Annaler, 81A, 4, 555-561, 1999.

Ferretti, A., Prati, C., and Rocca, F.: Permanent Scatterers in SAR interferometry, IEEE Transactions of Geosciences and Remote Sensing, 39, 1, 8-20, 2001.

Fischer, L.: Monte Rosa Ostwand - Geologie, Vergletscherung, Permafrost und Sturzereignisse in einer hochalpinen Steilwand, Diploma thesis, Department of Geography, University of Zurich, and Department of Earth Sciences, ETH Zurich, 2004.

Floricioiu, D. and Rott, H.: Seasonal and short-term variability of multifrequency, polarimetric radar backscatter of alpine terrain from SIR-C/X-SAR and AIRSAR data, IEEE Transactions on Geoscience and Remote Sensing, 39, 12, 2634-2648, 2001.

Forster, R. R., Jezek, K. C., Koenig, L., and Deeb, E.: Measurement of glacier geophysical properties from InSAR wrapped phase, IEEE Transactions on Geosciences and Remote Sensing, 41, 11, 2595-2604, 2003. 
Fox, A. J. and Nuttall, A. M.: Photogrammetry as a research tool for glaciology, Photogrammetric Record, 15, 89, 725-738, 1997.

Frauenfelder, R., Zgraggen-Oswald, S., Huggel, C., Kääb, A., Haeberli, W., Galushkin, I., and Polkvoy, A.: Permafrost distribution assessments in the North-Ossetian Caucasus: first results, Geophys. Res. Abstr., 7, 01619, 2005.

Friedman, K. S., Clemente, C. P., Pichel, W. G., and Li, X.: Routine monitoring of changes in the Columbia Glacier, Alaska, with synthetic aperture radar, Rem. Sen. Env., 70, 257-264, 1999.

Fruneau, B., Achache, J., and Delacourt, C.: Observation and modelling of the Saint-Etienne-de-Tinée landslide using SAR interferometry, Tectonophysics, 265, 3-4, 181-190, 1996.

Gamache, M.: Free and Low Cost Datasets for International Mountain Cartography, Proceedings, 4th ICA Mountain Cartography Workshop, Vall de Nuria, Catalonia, Spain, 2004.

Gamma, P.: dfwalk - Ein Murgang-Simulationsprogramm zur Gefahrenzonierung. PhD thesis, Department of Geography, University of Berne, Geographica Bernensia G66, 2000.

Gao, J. and Liu, Y. S.: Applications of remote sensing, GIS and GPS in glaciology: a review, Progress in Physical Geography, 25, 4, 520-540, 2001.

GAPHAZ: Joint international working group on glacier and permafrost hazards in mountains, Commission on Cryospheric Sciences and International Permafrost Association, http://www.geo. unizh.ch/gaphaz, 2004.

Geist, T., Lutz, E., and Stötter, J.: Airborne laser scanning technology and its potential for applications in glaciology, Proceedings, ISPRS Workshop on 3-D reconstruction from airborne laserscanner and INSAR data, Dresden, Germany, 2003.

Gens, R. and van Genderen, J. L.: SAR interferometry - Issues, techniques, applications, International Journal of Remote Sensing, 17, 1803-1835, 1996.

Grove, J. M.: Glacier fluctuations and hazards, Geographical Journal, 153, 351-369, 1987.

Grün, A. and Zhang, L.: Automatic DTM generation from threeline-scanners (TLS) images, Proceedings, International Symposium Photogrammetry meets Geoinformatics - Kartdagar 2002, Jönköping, Sweden, 2002.

Gudmundsson, G. H. and Bauder, A.: Towards an indirect determination of the mass-balance distribution of glaciers using the kinematic boundary condition, Geografiska Annaler, 81A, 4, 575$583,1999$.

Haeberli, W.: Frequency and characteristics of glacier floods in the Swiss Alps, Annals of Glaciology, 4, 85-90, 1983.

Haeberli, W. and Beniston, M.: Climate change and its impacts on glaciers and permafrost in the Alps, AMBIO, 27, 4, 258-265, 1998.

Haeberli, W., Huggel, C., Kääb, A., Oswald, S., Polvoj, A., Zotikov, I., and Osokin, N.: The Kolka-Karmadon rock/ice slide of 20 September 2002 - an extraordinary event of historical dimensions in North Ossetia (Russian Caucasus), J. Glaciol., in press, 2005.

Haeberli, W., Kääb, A., Paul, F., Chiarle, M., Mortara, G., Mazza, A., and Richardson, S.: A surge-type movement at Ghiacciaio del Belvedere and a developing slope instability in the east face of Monte Rosa, Macugnaga, Italian Alps, Norwegian Journal of Geography, 56, 2, 104-111, 2002.

Haeberli, W., Kääb, A., Vonder Mühll, D., and Teysseire, P.: Prevention of debris flows from outbursts of periglacial lakes at Gruben, Valais, Swiss Alps, J. Glaciol., 47, 156, 111-122, 2001.

Haeberli, W., Rickenmann, D., Zimmermann, M., and Rösli, U.: Investigation of 1987 debris flows in the Swiss Alps: general concept and geophysical soundings, Hydrology in moutainous regions II, artificial reservois, water and slopes, IAHS, 194, 303 310, 1990.

Haeberli, W. and Röthlisberger, H.: Beobachtungen zum Mechanismus und zu den Auswirkungen von Kalbungen am Grubengletscher (Saastal, Schweiz), Zeitschrift für Gletscherkunde und Glazialgeologie, 11, 2, 221-228, 1975.

Haeberli, W., Wegmann, M., and Vonder Mühll, D.: Slope stability problems related to glacier shrinkage and permafrost degradation in the Alps, Eclogae Geologicae Helvetiae, 90, 407-414, 1997.

Hall, D., Chang, A. T. C., Foster, J. L., Benson, C. S., and Kovalick, W. M.: Comparison of in situ and Landsat derived reflectances of Alaskan glaciers, Rem. Sen. Env., 28, 493-504, 1989.

Harbitz, C., Harbitz, A., and Nadim, F.: On probability analysis in snow avalanche hazard zonation, Annals of Glaciology, 32, 290 298, 2001.

Hauber, E., Slupetzky, H., Jaumann, R., Wewel, F., Gwinner, K., and Neukum, G.: Digital and automated high resolution stereo mapping of the Sonnblick glacier (Austria) with HRSC-A. Proceedings, EARSeL-SIG-Workshop Land Ice and Snow, Dresden, Germany, 246-254, 2000.

Hirano, A., Welch, R., and Lang, H.: Mapping from ASTER stereo image data: DEM validation and accuracy assessment, ISPRS Journal of Photogrammetry and Remote Sensing, 57, 5-6, 356370, 2003.

Hoelzle, M.: Mapping and modelling of mountain permafrost distribution in the Alps, Norwegian Journal of Geography, 50, 11-15, 1996.

Hoelzle, M., Wagner, S., Kääb, A., and Vonder Mühll, D.: Surface movement and internal deformation of ice-rock mixtures within rock glaciers in the Upper Engadin, Switzerland, Proceedings, 7th International Conference on Permafrost, Yellowknife, Canada, 465-472, 1998.

Honikel, M.: Fusion of spaceborne stereo-optical and interferometric SAR data for digital terrain model generation, Mitteilungen des Institutes für Geodäsie und Photogrammetrie, 76, 2002.

Huggel, C.: Assessment of glacial hazards based on remote sensing and GIS modeling, Department of Geography, University of Zurich, Physical Geography Series, 44, 2004.

Huggel, C., Haeberli, W., Kääb, A., Ayros, E., and Portocarrero, C.: Assessment of glacier hazards and glacier runoff for different climate scenarios based on remote sensing data: a case study for a hydropower plant in the Peruvian Andes, EARSel eProceedings, 2, 22-33, 2003a.

Huggel, C., Haeberli, W., Kääb, A., Bieri, D., and Richardson, S.: Assessment procedures for glacial hazards in the Swiss Alps, Canadian Geotechnical Journal, 41, 6, 1068-1083, 2004a.

Huggel, C., Kääb, A., Haeberli, W., and Krummenacher, B.: Regional-scale GIS-models for assessment of hazards from glacier lake outbursts: evaluation and application in the Swiss Alps, Nat. Hazards Earth Sys. Sci., 3, 6, 647-662, 2003b,

SRef-ID: 1684-9981/nhess/2003-3-647.

Huggel, C., Kääb, A., Haeberli, W., Teysseire, P., and Paul, F.: Satellite and aerial imagery for analysing high mountain lake hazards, Canadian Geotechnical Journal, 39, 2, 316-330, 2002.

Huggel, C., Kääb, A., Reynolds, J. M., and Heald, A.: Impactoriented models for potential lake outbursts and ASTER-based application in the Peruvian Andes. Proceedings, Fachtagung Schweizerische Geomorphologische Gesellschaft, Erstfeld, 129143, 2004b.

Huggel, C., Kääb, A., and Salzmann, N.: GIS-based modeling of glacial hazards and their interactions using Landsat TM and 
Ikonos imagery, Norwegian Journal of Geography, 58, 61-73, 2004c.

Huggel, C., Zgraggen-Oswald, S., Haeberli, W., Kääb, A., Polkvoj, A., Galushkin, I. and Evans, S.G.: The 2002 rock/ice avalanche at Kolka/Karmadon, Russian Caucasus: assessment of extraordinary avalanche formation and mobility, and application of QuickBird satellite imagery, Nat. Hazards Earth Sys. Sci., 5, 173-187, 2005, SRef-ID: 1684-9981/nhess/2005-5-173.

Iverson, R. M., Schilling, S. P., and Vallance, J. W.: Objective delineation of lahar-inundation hazard zones. Geological Society of America Bulletin, 110, 8, 972-984, 1998.

Janeras, M., Navarro, M., Arnó, G., Ruiz, A., Kornus, W., Talaya, J., Barberà, M. and López, F.: LIDAR applications to rock fall hazard assessment in Vall de Núria. Proceedings, 4th ICA Mountain Cartography Workshop, Vall de Núria, Catalonia, Spain, 2004.

Jiskoot, H., Pederson, A. K., and Murray, T.: Multi-model photogrammetric analysis of the 1990s surge of Sortebræ, East Greenland, J. Glaciol., 47, 677-687, 2001.

Joughin, I. R., Kwok, R., and Fahnestok, M. A.: Interferometric estimation of three-dimensional ice-flow using ascending and descending passes, IEEE Transactions on Geoscience and Remote Sensing, 36, 1, 25-37, 1999.

Julio Miranda, P. and Delgado Granados, H.: Fast hazard evaluation employing digital photogrammetry: Popocatepetl glaciers, Mexico, Geofísica Internacional, 42, 2, 275-283, 2003.

Julio Miranda, P., Gonzales-Huesca, A. E., Delgado Granados, H., and Kääb, A.: Ice-fire interactions on Popocatépetl volcano (Mexico): case study of the 22 January 2001 eruption, Zeitschrift für Geomorphologie, in press, 2005.

Kääb, A.: Photogrammetrische Analyse zur Früherkennung gletscher- und permafrostbedingter Naturgefahren im Hochgebirge, Mitteilungen der Versuchsanstalt für Wasserbau, Hydrologie und Glaziologie der ETH Zürich, 145, Zürich, 182 pp., 1996.

Kääb, A.: Photogrammetry for early recognition of high mountain hazards: new techniques and applications, Phys. Chem. Earth B., 25, 9, 765-770, 2000.

Kääb, A.: Monitoring high-mountain terrain deformation from airand spaceborne optical data: examples using digital aerial imagery and ASTER data, ISPRS Journal of Photogrammetry and Remote Sensing, 57, 1-2, 39-52, 2002.

Kääb, A.: Mountain glaciers and permafrost creep. Methodical research perspectives from earth observation and geoinformatics technologies, Habilitation thesis, Department of Geography, University of Zurich, 205 pp., 2004.

Kääb, A.: Combination of SRTM3 and repeat ASTER data for deriving alpine glacier flow velocities in the Bhutan Himalaya, Rem. Sen. Env., 94, 4, 463-474, 2005.

Kääb, A. and Funk, M.: Modelling mass balance using photogrammetric and geophysical data, A pilot study at Gries glacier, Swiss Alps, J. Glaciol., 45, 151, 575-583, 1999.

Kääb, A. and Haeberli, W.: Evolution of a high-mountain thermokarst lake in the Swiss Alps, Arctic, Antarctic, and Alpine Research, 33, 4, 385-390, 2001.

Kääb, A., Haeberli, W., and Gudmundsson, G.H.: Analysing the creep of mountain permafrost using high precision aerial photogrammetry: 25 years of monitoring Gruben rock glacier, Swiss Alps, Permafrost and Periglacial Processes, 8, 4, 409-426, 1997.

Kääb, A., Haeberli, W., Huggel, C., and Paul, F.: Glacier- and permafrost-related hazards in high mountains: integrative assessment in the Swiss Alps based on remote sensing and geoinformation systems. Proceedings, X Congresso Peruano de Geologia, Lima, CD-ROM, 2000.
Kääb, A., Huggel, C., Barbero, S., Chiarle, M., Cordola, M., Epifani,, F., Haeberli, W., Mortara, G., Semino, P., Tamburini, A., and Viazzo, G.: Glacier hazards at Belvedere Glacier and the Monte Rosa east face, Italian Alps: processes and mitigation, Proceedings, Interpraevent, 1, 67-78, 2004a.

Kääb, A., Huggel, C., Paul, F., Wessels, R., Raup, B., Kieffer, H., and Kargel, J.: Glacier monitoring from ASTER imagery: accuracy and applications, EARSel eProceedings, 2, 43-53, 2003a.

Kääb, A., Isakowski, Y., Paul, F., Neumann, A., and Winter, R.: Glaziale und periglaziale Prozesse: Von der statischen zur dynamischen Visualisierung, Kartographische Nachrichten, 53, 5, 206-212, 2003b.

Kääb, A., Lefauconnier, B., and Melvold, K.: Flow field of Kronebreen, Svalbard, using repeated Landsat7 and ASTER data, Annals of Glaciology, 42, in press, 2004b.

Kääb, A. and Reichmuth, T.: Advance mechanisms of rockglaciers, Permafrost and Periglacial Processes, 16, 2, 187-193, 2005.

Kääb, A., Reynolds, J. M., and Haeberli, W.: Glacier and permafrost hazards in high mountains, in: Global Change and Mountain Regions (A State of Knowledge Overview), edited by: Huber, U. M., Bugmann, H. K. M., and Reasoner, M. A., Advances in Global Change Research, Springer, Dordrecht, 225234, 2005.

Kääb, A. and Vollmer, M.: Surface geometry, thickness changes and flow fields on creeping mountain permafrost: automatic extraction by digital image analysis, Permafrost and Periglacial Processes, 11, 4, 315-326, 2000.

Kääb, A. and Weber, M.: Development of transverse ridges on rockglaciers. Field measurements and laboratory experiments, Permafrost and Periglacial Processes, 15, 4, 379-391, 2004.

Kääb, A., Wessels, R., Haeberli, W., Huggel, C., Kargel, J., and Khalsa, S. J. S.: Rapid ASTER imaging facilitates timely assessment of glacier hazards and disasters, EOS Transactions, American Geophysical Union, 84, 13, 117, 121, 2003c.

Kaufmann, V. and Ladstädter, R.: Spatio-temporal analysis of the dynamic behaviour of the Hochebenkar rock glaciers (Oetztal Alps, Austria) by means of digital photogrammetric methods, Grazer Schriften der Geographie und Raumforschung, 37, 119$140,2002$.

Kaufmann, V. and Ladstädter, R.: Documentation of the retreat of a small debris-covered cirque glacier (Goessnitzkees, Austrian Alps) by means of teresstrial photogrammetry, Proceedings, 4th ICA Mountain Cartography Workshop, Vall de Núria, Catalonia, Spain, 2004.

Kaufmann, V. and Plösch, R.: Reconstruction and visualisation of the retreat of two small cirque glaciers in the Austrian Alps since 1850, in: High Mountain Cartography 2000, edited by: Buchroithner, M., Kartographische Bausteine, Dresden University of Technology, 18, 239-253, 2000.

Keller, P., Keller, I., and Itten, K. I.: Combined hyperspectral data analysis of two Alpine lakes using CASI and DAIS 7915 imagery, Proceedings, EARSeL workshop, Zurich, CD-ROM, 1998.

Kelley, R., Engeset, R., Kennett, M., Barrett, E. C., and Theakstone, W.: Characteristic snow and ice properties of a Norwegian ice cap determined from complex ERS SAR. Proceedings, 3rd ERS Symposium (ESA), Florence, Italy, CD-ROM, 1997.

Kenyi, L. W. and Kaufmann, V.: Estimation of alpine permafrost surface deformation using InSAR data, Proceedings, IEEE International Geoscience and Remote Sensing Symposium, Sydney, Australia, CD-ROM, 2001.

Kenyi, L. W. and Kaufmann, V.: Measuring rock glacier surface 
deformation using SAR interferometry, Proceedings, Eighth International Conference on Permafrost, Zurich, Balkema, 1, 537$541,2003$.

Kerle, N. and Oppenheimer, C.: Satellite remote sensing as a tool in lahar disaster management, Disasters, 26, 2, 140-160, 2002.

Kniveton, D. R., De Graff, P. J., Granica, K., and Hardy, R. J.: The development of a remote sensing based technique to predict debris flow triggering conditions in the French Alps, International Journal of Remote Sensing, 21, 3, 419-434, 2000.

Knizhnikov, Y. F., Gelman, R. N., Osipova, G. B., and Tsvetkov, D. G.: Aerophotogrammetric study of ice movement in surging glaciers, Zeitschrift für Gletscherkunde und Glazialgeologie, 34, 1, 69-84, 1998

König, M., Winther, J.-G., and Isaksson, E.: Measuring snow and ice properties from satellite, Reviews of Geophysics, 39, 1, 1-27, 2001.

Kotlyakov, V. M., Rototaeva, O. V., and Nosenko, G. A.: The September 2002 Kolka glacier catastrophe in North Ossetia, Russian Federation, Evidence and Analysis, Mountain Research and Development, 24, 1, 78-83, 2004.

Lewkowicz, A. G. and Duguay, C. R.: Detection of permafrost features using SPOT panchromatic imagery, Fosheim Peninsula, Ellesmere Island, N.W.T., Canadian Journal of Remote Sensing, 25, 1, 34-44, 1999.

Li, Z., Xu, Z., Cen, M., and Ding, X.: Robust surface matching for automated detection of local deformations using least-medianof-squares estimator, Photogrammetric Engineering and Remote Sensing, 67, 11, 1283-1292, 2001.

Liang, L. and MacKay, D. S.: A general model of watershed extraction and representation using globally optimal flow paths and up-slope contributing areas, International Journal of Geographic Information Science, 14, 4, 337-358, 2000.

Lillesand, T. M. and Kieffer, R. W.: Remote Sensing and image interpretation - fourth edition, Wiley, New York etc., 2000.

Liu, J. G., Mason, P. J., Clerici, N., Chen, S., Davis, A., Miao, F., Deng, H., and Liang, L.: Landslide hazard assessment in the Three Gorges area of the Yangtze river using ASTER imagery: Zigui-Badong, Geomorphology, 61, 1-2, 171-187, 2005.

Luckman, A., Murray, T., and Strozzi, T.: Three-dimensional surface flow evolution throughout a glacier surge measured by satellite radar interferometry, Geophys. Res. Lett., 29, 23, doi:10.1029/2001GL014570, 2002.

Lutz, E., Geist, T., and Stötter, J.: Investigations of airborne laser scanning signal intensity on glacial surfaces - Utilizing comprehensive laser geometry modelling and orthophoto surface modelling (A case study: Svartisheibreen, Norway), Proceedings, ISPRS Workshop on 3-D reconstruction from airborne laserscanner and INSAR data, Dresden, Germany, 2003.

Maisch, M., Wipf, A., Denneler, B., Battaglia, J., and Benz, C.: Die Gletscher der Schweizer Alpen: Gletscherhochstand 1850 - Aktuelle Vergletscherung - Gletscherschwund-Szenarien 21. Jahrhundert, Schlussbericht NFP31 vdf Hochschulverlag, ETH Zurich, 1999.

Major, J. J. and Newhall, C. G.: Snow and ice perturbation during historical volcanic eruptions and the formation of lahars and floods, Bulletin of Volcanology, 52, 1-27, 1989.

Mantovani, F., Soeters, R., and Van Westen, C. J.: Remote sensing techniques for landslide studies and hazard zonation in Europe, Geomorphology, 15, 3-4, 213-225, 1996.

Mattar, K. E., Vachon, P. W., Geudtner, D., Gray, A. L., Cumming, I. G., and Brugman, M.: Validation of alpine glacier velocity measurements using ERS tandem-mission SAR data, IEEE
Transactions on Geosciences and Remote Sensing, 36, 3, 974 984, 1998.

Meissl, G.: Modellierung der Reichweite von Felsstürzen Fallbeispiele zur GIS-gestützten Gefahrenbeurteilung aus dem Bayrischen und Tiroler Alpenraum, Innsbrucker Geographische Studien, Innsbruck, 1998.

Michel, R. and Rignot, E.: Flow of Moreno Glaciar, Argentina, from repeat-pass Shuttle Imaging Radar images: comparison of the phase correlation method with radar interferometry, J. Glaciol., 45, 149, 93-100, 1999.

Mool, P. K., Bajracharya, S. R., and Joshi, S. P.: Inventory of glaciers, glacial lakes and glacial lake outburst floods, Nepal, International Centre for Integrated Mountain Development, Kathmandu, Nepal, 365 pp., 2001a.

Mool, P. K., Wangda, D., Bajrachary, S. R., Kunzang, K., Gurung, D. R., and Joshi, S. P.: Inventory of glaciers, glacial lakes and glacial lake outburst floods, Bhutan, International Centre for Integrated Mountain Development, Kathmandu, Nepal, 227 pp., $2001 b$.

Moorman, B. J. and Vachon, P. W.: Detecting ground ice melt with interferometric synthetic aperture radar, Proceedings, 20th Canadian Symposium on Remote Sensing, Calgary, Canada, 1998.

Mora, P., Baldi, P., Casula, C., Fabris, M., Ghirotti, M., Mazzini, M., and Pesci, A.: Global Positioning Systems and digital photogrammetry for the monitoring of mass movements: application to the Ca' di Malta landslide (northern Apennines, Italy), Engineering Geology, 68, 1-2, 103-121, 2003.

Mostyn, G. R. and Li, V.: Probabilistic slope analysis - state of play, Proceedings, Conference on Probabilistic Methods in Geotechnical Engineering, Canberra, Australia, A.A. Balkema, Rotterdam, 89-110, 1993.

Müller, D.: Auflaufen und Überschwappen von Impulswellen an Talsperren, Mitteilungen VAW/ETH Zürich, 137, 1995.

Nagler, T., Mayer, C., and Rott, H.: Feasibility of DInSAR for mapping complex motion fields of Alpine ice- and rock-glaciers, Proceedings, 3rd International Symposium on Retrieval of Bio- and Geophysical Parameters from SAR Data for Land Application, Sheffield, UK, SP, 475, 377-382, 2002.

Noetzli, J.: Felsstürze aus Permafrost über Gletschern, Diploma thesis, Department of Geography, University of Zurich, 2003.

Noetzli, J., Hoelzle, M., and Haeberli, W.: Mountain permafrost and recent Alpine rock-fall events: a GIS-based approach to determine critical factors, Proceedings, 8th International Conference on Permafrost, Zurich, Balkema, 827-832, 2003.

Noetzli, J., Huggel, C., Hoelzle, M., and Haeberli, W.: GIS-based modelling of rock/ice avalanches from Alpine permafrost areas, Computational Geosciences, in press, 2005.

Ostir, K., Veljanovski, T., Podobnikar, T., and Stancic, Z.: Application of satellite remote sensing in natural hazard management: the Mount Mangart landslide case study. International Journal of Remote Sensing, 24, 20, 3983-4002, 2003.

Paul, F.: Changes in glacier area in Tyrol, Austria, between 1969 and 1992 derived from Landsat 5 Thematic Mapper and Austrian Glacier Inventory data, International Journal of Remote Sensing, 23, 4, 787-799, 2002.

Paul, F.: The new Swiss glacier inventory 2000 - Application of remote sensing and GIS, PhD thesis, Department of Geography, University of Zurich, 2004.

Paul, F., Huggel, C., and Kääb, A.: Mapping of debris-covered glaciers using multispectral and DEM classification techniques, Rem. Sen. Env., 89, 4, 510-518, 2004a.

Paul, F. and Kääb, A.: Challenges for glacier inventorying from 
multispectral satellite data in the Canadian Arctic: Cumberland Peninsula, Baffin Island, Annals of Glaciology, 42, in press, 2004.

Paul, F., Kääb, A., Maisch, M., Kellenberger, T., and Haeberli, W.: The new remote-sensing-derived Swiss glacier inventory: I. Methods, Annals of Glaciology, 34, 355-361, 2002.

Paul, F., Kääb, A., Maisch, M., Kellenberger, T., and Haeberli, W.: Rapid disintegration of Alpine glaciers observed with satellite data, Geophys. Res. Lett., L21402, doi:10.1029/2004GL020816, 2004b.

Pilgrim, L.: Robust estimation applied to surface matching, ISPRS Journal of Photogrammetry and Remote Sensing, 51, 243-257, 1996a.

Pilgrim, L. J.: Surface matching and difference detection without the aid of control points, Survey Review, 33, 259, 291-303, 1996 b.

Pitkänen, T. and Kajutti, K.: Close-range photogrammetry as a tool in glacier change detection, ISPRS International Archives of Photogrammetry, Remote Sensing and Spatial Information Sciences, XXXV(B7), 769-773, 2004.

Powers, P. S., Chiarle, M., and Savage, W. Z.: A digital photogrammetric method for measuring horizontal surficial movements on the Slumgullion earthflow, Hinsdale county, Colorado, Computers and Geosciences, 22, 6, 651-663, 1996.

Quincey, D., Lucas, R. M., Richardson, S. D., Glasser, N. F., Hambrey, M. J., and Reynolds, J. M.: Optical remote sensing techniques in high-mountain environments: application to glacial hazards, Progress in Physical Geography, in press, 2005.

Rabus, B., Eineder, M., Roth, A., and Bamler, R.: The shuttle radar topography mission - a new class of digital elevation models acquired by spaceborne radar, ISPRS Journal of Photogrammetry and Remote Sensing, 57, 4, 241-262, 2003.

Renouard, L., Perlant, F., and Nonin, P.: Comparison of DEM generation from SPOT stereo and ERS interferometric SAR data, EARSeL Advances in Remote Sensing - Topography from Space, 4, 2, 103-109, 1995.

Reynolds, J. M.: On the formation of supraglacial lakes on debris-covered glaciers, in: Debris-Covered Glaciers, edited by: Nakawo, M., Raymond, C. F., and Fountain, A., IAHS publications, 264, 153-161, 2000.

Richardson, S. D. and Reynolds, J. M.: An overview of glacial hazards in the Himalayas, Quaternary International, 65/66, 31-47, 2000.

Rignot, E., Forster, R., and Isacks, B.: Interferometric radar observations of Glaciar San Rafael, Chile, J. Glaciol., 42, 141, 279291, 1996.

Rignot, E., Rivera, A., and Casassa, G.: Contribution of the Patagonia Icefields of South America to sea level rise, Science, 302, 434-437, 2003.

Roer, I., Kääb, A., and Dikau, R.: Rockglacier kinematics derived from small-scale aerial photography and digital airborne pushbroom imagery, Zeitschrift für Geomorphologie, 49, 1, 73-87, 2005.

Rolstad, C., Amlien, J., Hagen, J. O., and Lundén, B.: Visible and near-infrared digital images for determination of ice velocities and surface elevation during a surge on Osbornebreen, a tidewater glacier in Svalbard, Annals of Glaciology, 24, 255-261, 1997.

Rott, H.: Thematic studies in alpine areas by means of polarimetric SAR and optical imagery, Adv. Space Res., 14, 3, 217-226, 1994.

Rott, H., Scheuchel, A., Siegel, A., and Grasemann, B.: Monitoring very slow slope movements by means of SAR interferometry: a case study from mass waste above a reservoir on the Ötztal Alps, Austria, Geophys. Res. Lett., 26, 11, 1629-1632, 1999.

Rott, H. and Strobl, D.: Synergism of SAR and Landsat TM imagery for thematic mapping in complex terrain, Adv. Space Res. 12, 7, 425-431, 1992.

Sabins, F. F.: Remote sensing: principles and interpretation, Freeman, New York, 1997.

Salzmann, N., Kääb, A., Huggel, C., Allgöwer, B., and Haeberli, W.: Assessment of the hazard potential of ice avalanches using remote sensing and GIS-modelling, Norwegian Journal of Geography, 58, 74-84, 2004.

Schlaefli, S.: Interaktive, GIS-basierte Modellierung von Murgängen, Fels- und Eislawinen, Diploma thesis, Department of Geography, University of Zurich, 2005.

Schowengerdt, R. A.: Remote sensing. Models and methods for image processing - second edition, Academic Press, San Diego and Chestnut Hill, 1997.

Sheridan, M. F., Hubbard, B., Carrasco-Nunez, G., and Siebe, C.: Pyroclastic flow hazard at Volcan Citlaltepetl, Nat. Haz., 33, 2, 209-221, 2004.

Silverio, W. and Jaquet, J.-M.: Glacial cover mapping (1987-1996) of the Cordillera Blanca (Peru) using satellite imagery, Rem. Sens. Env., 95, 342-350, 2005.

Singhroy, V. and Molch, K.: Characterizing and monitoring rockslides from SAR techniques, Adv. Space Res., 33, 3, 290-295, 2004.

Skvarca, P., Raup, B., and De Angelis, H.: Recent behaviour of Glaciar Upsala, a fast-flowing calving glacier in Lago Argentino, southern Patagonia, Annals of Glaciology, 36, 184-188, 2003.

Squarzoni, C., Delacourt, C., and Allemand, P.: Nine years of spatial and temporal evolution of the La Valette landslide observed by SAR interferometry, Engineering Geology, 68, 1-2, 53-66, 2003.

Stebler, O., Barmettler, A., Divis, L., Small, D., Schwerzmann, A., Meier, E., and Nüesch, D.: Swiss Alpine Airborne SAR Experiment (SASARE) part I: Multi-baseline polarimetric SAR interferometry studies at L- and P-band, Proceedings, IEEE International Geoscience and Remote Sensing Symposium (IGARSS), Anchorage, Alaska, 2, 1116-1120, 2004.

Stebler, O., Meier, E., and Nüesch, D.: Multi-baseline polarimetric SAR interferometry - first experimental spaceborne and airborne results, ISPRS Journal of Photogrammetry and Remote Sensing, 56, 3, 149-166, 2002.

Stevens, N. F., Garbeil, H., and Mouginis-Mark, P. J.: NASA EOS Terra ASTER: Volcanic topographic mapping and capability, Rem. Sen. Env., 90, 405-414, 2004.

Stevens, N. F., Manville, V., and Heron, D. W.: The sensitivity of a volcanic flow model to digital elevation model accuracy: experiments with digitised map contours and interferometric SAR at Ruapehu and Taranaki volcanoes, New Zealand, Journal of Volcanology and Geothermal Research, 119, 1-4, 89-105, 2003.

Sties, M., Krüger, S., Mercer, J. B., and Schnick, S.: Comparison of digital elevation data from airborne laser and interferometric SAR systems, International Archives of Photogrammetry and Remote Sensing, 33, 866-873, 2000.

Strozzi, T., Gudmundsson, H., and Wegmüller, U.: Estimation of the surface displacement of Swiss alpine glaciers using satellite radar interferometry, EARSel eProceedings, 2, 1, 3-7, 2003a.

Strozzi, T., Kääb, A., and Frauenfelder, R.: Detecting and quantifying mountain permafrost creep from in-situ, airborne and spaceborne remote sensing methods, International Journal of Remote Sensing, 25, 15, 2919-2931, 2004. 
Strozzi, T., Luckman, A., Murray, T., Wegmüller, U., and Werner, C. L.: Glacier motion estimation using SAR offset-tracking procedures, IEEE Transactions on Geosciences and Remote Sensing, 40, 11, 2384-2391, 2002.

Strozzi, T., Wegmüller, U., Tosi, L., Bitelli, G., and Spreckels, V.: Land subsidence monitoring with differential SAR interferometry, Photogrammetric Engineering and Remote Sensing, 67, 11, 1261-1270, 2001.

Strozzi, T., Wegmüller, U., Wiesmann, A., and Werner, C.: Validation of the X-SAR SRTM DEM for ERS and JERS SAR geocoding and 2-pass differential interferometry in alpine regions, Proceedings, IGARSS'03, Toulouse, France, 2003b.

Tarchi, D., Casagli, N., Fanti, R., Leva, D.D., Luzi, G., Pasuto, A., Pieraccini, M., and Silvano, S.: Landslide monitoring by using ground-based SAR interferometry: an example of application to the Tessina landslide in Italy, Engineering Geology, 68, 1-2, 1530, 2003.

Tinti, S., Maramai, A., and Cerutti, A. V.: The Miage Glacier in the Valley of Aosta (western Alps, Italy) and the extraordinary detachment which occurred on 9 August 1996, Phys. Chem Earth A., 24, 2, 157-161, 1999.

Toutin, T.: DEM generation from new VIR Sensors: Ikonos, ASTER and Landsat 7, Proceedings, IGARSS '01, Sydney, Australia, 2001.

Toutin, T.: Three-dimensional topographic mapping with ASTER stereo data in rugged topography, IEEE Transactions on Geoscience and Remote Sensing, 40, 10, 2241-2247, 2002.

Toutin, T. and Gray, L.: State-of-the-art of elevation extraction from satellite SAR data, ISPRS Journal of Photogrammetry and Remote Sensing, 55, 1, 13-33, 2000.

Vachon, P. W., Geudtner, D., Gray, A. L., Mattar, K., Brugman, M., and Cumming, I. G.: Airborne and Spaceborne SAR Interferometry: Application to the Athabasca Glacier Area, Proceedings, IGARSS '96, Lincoln, Nebraska, 2255-2257, 1996.

Wagnon, P., Ribstein, P., Kaser, G., and Berton, P.: Energy balance and runoff seasonality of a Bolivian glacier, Global and Planetary Change, 22, 49-58, 1999.

Walder, J. S. and Driedger, C. L.: Frequent outburst floods from South Tahoma Glacier, Mount Rainier, USA: relation to debris flows, meteorological origin and implications for subglacial hydrology, J. Glaciol., 41, 1-10, 1995.

Walder, J. S., Watts, P., Sorensen, O. E., and Janssen, K.: Water waves generated by subaerial mass flows, J. Geophys. Res., 108, B5, 2236-2255, 2003.

Wang, Z. and Li, S.: Detection of winter frost heaving of the active layer of arctic permafrost using SAR differential interferometry, Proceedings, IEEE Geoscience and Remote Sensing Symposium IGARSS’99, Hamburg, 1946-1948, 1999.
Weber, D. and Herrmann, A.: Contribution of digital photogrammetry in spatio-temporal knowledge of unstable slopes: the example of the Super-Saute landslide (Alpes-de-Haute-Provence, France), Bulletin de la Societe Geologique de France, 171, 6 , 637-648, 2000.

Weidmann, Y.: Kombination von ASTER- und SRTMHöhenmodellen für die Abschätzung von Naturgefahren im Pamir Gebirge, Tadschikistan, Diploma thesis, University of Applied Sciences, Muttenz, Basel, 2004.

Wessels, R., Kargel, J. S., and Kieffer, H. H.: ASTER measurement of supraglacial lakes in the Mount Everest region of the Himalaya, Annals of Glaciology, 34, 399-408, 2002.

Weydahl, D. J.: Analysis of ERS tandem SAR coherence from glaciers, valleys, and fjord ice on Svalbard. IEEE Transactions on Geoscience and Remote Sensing, 39, 9, 2029-2039, 2001.

Zemp, M., Kääb, A., Hoelzle, M., and Haeberli, W.: GIS-based modelling of glacial sediment balance, Zeitschrift für Geomorphologie, Supplements, 138, 113-129, 2005.

Zhang, L. and Grün, A.: Automatic DSM generation from linear array imagery data, International Archives of Photogrammetry and Remote Sensing, 15, B3, 128-133, 2004.

Zhang, W.: Identification of glaciers with surge characteristics on the Tibetan Plateau, Annals of Glaciology, 16, 168-172, 1992.

Zimmermann, M. and Haeberli, W.: Climatic change and debris flow activity in high-mountain areas - a case study in the Swiss Alps, in: Catena Supplement, edited by: Boer, M. and Koster, E., 22, 59-72, 1992.

Zimmermann, M., Mani, P., Gamma, P., Gsteiger, P., Hunziker, G., and Heiniger, O.: Beurteilung der Murganggefährdung mit Hilfe eines Geographischen Informationssystems. Analyse der räumlichen Entwicklung infolge von Klimaänderungen, Schlussbericht NFP31, Verlag der Fachvereine ETH Zurich, Zurich, 1997.

Zollinger, S.: Ableitung von Parametern für die Identifikation und Beobachtung gefährlicher Gletscherseen in Nepal aus ASTER Satellitendaten, Diploma thesis, Department of Geography, University of Zurich, 2003.

Zomer, R., Ustin, S., and Ives, J.: Using satellite remote sensing for DEM extraction in complex mountainous terrain: landscape analysis of the Makalu Barun National Park of eastern Nepal, International Journal of Remote Sensing, 23, 1, 125-143, 2002.

Zweifel, A.: Impulswellen: Effekte der Rutschdichte und der Wassertiefe, Mitteilungen VAW/ETH Zürich, 186, 2004. 